\title{
NBSIR 80-2130
}

\section{A Survey of Field Experience With Smoke Detectors in Health Care Facilities}

Richard W. Bukowski and Sharon M. Istvan

Center for Fire Research

National Engineering Laboratory

National Bureau of Standards

U.S. Department of Commerce

Washington, DC 20234

October 1980

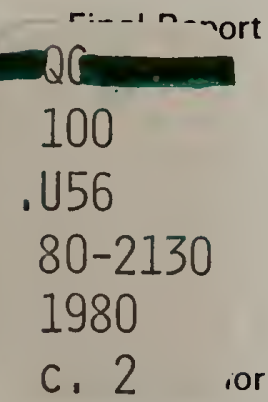

U.S. Department of Health and Human Services

Washington, DC 20201 



\section{A SURVEY OF FIELD EXPERIENCE WITH SMOKE DETECTORS IN HEALTH CARE FACILITIES}

Richard W. Bukowski and Sharon M. Istvan

Center for Fire Research

National Engineering Laboratory

National Bureau of Standards

U.S. Department of Commerce

Washington, DC 20234

October 1980

Final Report

Prepared for:

U.S. Department of Health and Human Services

Washington, DC 20201

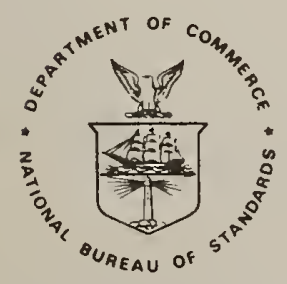

U.S. DEPARTMENT OF COMMERCE, Philip M. Klutznick, Secretary 


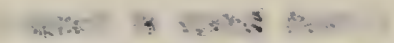

an+

: \& 1 
LIST OF FIGURES

LIST OF TABLES

Abstract

1. INTRODUCTION

1.1 Purpose

2. BACKGROUND

2.1 Previous Studies . . . . . . . . . . . . . . . . . . . . . 2

2.2 Review of Code Requirements for Smoke Detectors in Health Care Facilities

3. SURVEY METHOD

3.1 Sampling änd Data Collection

3.2 Survey Form . . . . . . .

3.3 Data Analysis Technique

4. RESULTS

4.1 Data Received

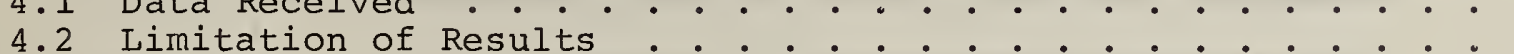

5. DISCUSSION OF RESULTS . . . . . . . . . . . . . . . . . . . . . . . . 7

5,1 Distribution of Alarms by Manufacturer and Model . . . . . . . 7

5.2 Distribution of Alarms bY Type of Detector . . . . . . . . . . 8

5.3 Distribution of Data by Detector Location . . . . . . . . . . 8

5.4 Maintenance ........................... . . . . . . . . . 9

5.4 .1 Cleaning . . . . . . . . . . . . . . . . 9

5.4.2 Testing..................... . 9

6. SUMMARY OF FINDINGS . . . . . . . . . . . . . . . . . . . . . 10

7. NEED FOR FURTHER DATA . . . . . . . . . . . . . . . . . . . . 11

8. REFERENCES •. . . . . . . . . . . . . . . . . . . . . . 11

FIGURES • • . . . . . . . . . . . . . . . . . . . . . . 12-13

TABLES • • • • • . . . . . . . . . . . . . . . . . . . . $14-22$

APPENDIX A - A COMPLETE TABULATION OF THE RESULTS FROM THE SURVEY QUESTIONS 
Figure 1. Smoke detector survey form . . . . . . . . . . . . . .

Figure 2. Breakdown of forms received . . . . . . . . . . . . . . .

\section{LIST OF TABLES}

Page

Table 1. Regional breakdown of fifty states . . . . . . . . . . . 14

Table 2. Coded responses to the survey questions. . . . . . . . . . 15

Table 3. Number of forms and total number of detectors by manufacturer . . . . . . . . . . . . . . . 16

Table 4. Summary of false and real alarm frequency by manufacturer.

Table 5. Summary of false and real alarm frequency by type of

Table 6. Distribution of detectors by location . . . . . . . . . 18

Table 7. Sumary of false and real alarm frequency by location . • . 19

Table 8. Percent of total detectors cleaned by various methods . • 20

Table 9. Summary of false and real alarm frequency by cleaning method and cleaning frequency . . . . . . . . . . .

Table 10. Summary of false and real alarm frequency by testing method and testing frequency . . . . . . . . . . . . . 


\title{
A SURVEY OF FIELD EXPERIENCE WITH SMOKE DETECTORS IN HEALTH CARE FACILITIES
}

Richard W. Bukowski and Sharon M. Istvan

\begin{abstract}
A survey of health care facilities in eight states was conducted to gather data on experience with smoke detection systems. Requested information included detector manufacturer and model number, number of detectors and time in service, detector locations, numbers of false and real alarms and the methods and frequency of cleaning and testing the detectors. The results of the survey inaicate that about 70 percent of the detectors were ionization type, and 30 percent were of the photoelectric type. Fourteen percent of the total number of detectors were single-station, battery-operated, residential-type detectors, most of which were installed in health care facilities in only one of the eight states surveyed. Almost 80 percent of the detectors were installed in corridors and the average age of the detector installation was about Iive years. The detection systems were found to experience approximately 14 false alarms for each real fire detected with the highest false alarm rate occurring in detectors installed in laundry areas, storage areas, and kitchens. While over 88 percent of the systems were tested at least annually ( 55 percent tested monthly), almost half ( 45.7 percent) were never cleaned. Almost 11 percent of the installed systems were maintained under an outside service contract.
\end{abstract}

Key words: Detector location; false alarms; health care facilities; hospitals; ionization detectors; maintenance; NFPA 101; nursing homes; photoelectric detectors; smoke detectors; surveys.

\section{INTRODUCTION}

\subsection{Purpose}

The National Bureau of Standards (NBS), Center for Fire Research (CFR) is currently engaged in a five-year experimental program sponsored by the U.S. Department of Health and Human Services (HHS) to study fire protection techniques for health care facilities. One of the major segments of this program includes the conduct of full-scale experiments to obtain data on the response of automatic detection and suppression systems to fires in a patient room. While such experiments can provide important data on smoke detection system performance in specific fire scenarios, they provide no data on how detection systems perform under non-fire conditions. The best way to obtain this type of data is by studying detection systems in actual installations.

As with all alarm systems, an effective fire detection system would detect the outbreak of all hostile fires, but might be impractical because of a high false alarm rate. It is therefore important to identify the factors which affect false alarm rate so that proper steps can be taken to minimize false alarms. This survey was conducted to provide information in this area. 


\section{BACKGROUND}

\subsection{Previous Studies}

Very little quantitative information on the false alarm history of installed smoke detection systems exists in the literature. In the U.S., most systems are "local systems", without connection to fire departments. While excessive false alarms are considered a nuisance, building owners rarely keep accurate records and rarely extend an effort to investigate and determine the cause of the false alarms. Even in Europe, where a much higher proportion of systems are connected to fire departments, those departments often do not keep detailed records on numbers of and reasons for false alarms.

In 1968, at the request of the Home Office, the U.K. Fire Research Station (FRS) undertook a study [1] to provide detection system false alarm information based on reporting forms completed by local fire departments. The reporting form was developed by FRS and sent to fire departments in England, Wales, and Scotland with instructions that all alarms (false and real) received from premises protected by automatic fire detection systems be investigated and the forms completed. Data were taken for the entire calendar year 1968 and a report of the study was published by Fry [1] in March 1970.

That study broke the data down into type of occupancy (where unfortunately, health care was not listed as a separate category) and type of system (e.g., heat, smoke, sprinkler, manual, etc.) and also attempted to categorize the reasons for the reported false alarms. For example, for smoke detection systems there were 1567 alarms reported to the fire departments. Of these, 1429 were false alarms, 101 were alarms to real fires by the alarm system and 37 were alarms to real fires reported by other means (e.g., telephone call). From this, Fry computed an aggregate false-to-real alarm ratio for the smoke detection systems of 14 to 1 . It should be noted that these data included only alarms received during the 12-month study period and made no allowances for the numbers of detectors installed in each system nor for the age of the system.

In analyzing the reported reasons for the 1429 false alarms, it was found that 37 percent were caused by excessive heat and smoke in the protected area from a non-fire source, such as from a manufacturing process. In addition, 30 percent were caused by defective detectors or control panels and 11 percent by system testing, maintenance, or other activities where the local fire department was not informed of the activity.

Another study on field performance of ionization-type smoke detector systems was initiated by Underwriters Laboratories Inc. (UL) in the fall of 1968 [2]. At that time, UL was developing a testing and approval standard for system type ionization smoke detectors. In order to gather data on the reasons for false alarms in these detectors, a questionnaire was prepared and distributed through central station operating companies and the UL Fire council. The intent was that, if certain predominant causes for false alarms could be identified, then test requirements could be incorporated into the standard to minimize the chances of false alarms from these sources.

\footnotetext{
${ }^{1}$ Numbers in brackets refer to the literature references listed at the end of this paper.
} 
The data returned in response to the questionnaire covered a total of 337 systems employing 7940 smoke detectors. Of the 337 systems, approximately 59 percent were installed in U.S. Federal Government facilities. A total of $1070 \mathrm{false}$ alarms were reported, 67 percent reported from known causes and 33 percent from unknown causes.

An analysis of the reported reasons for the false alarms indicated that, similar to Fry's results, the majority of false alarms occurred due to variations in ambient conditions (excessive heat or smoke) within the protected area. Other important causes of false alarms were also identified, including improper application or installation, and improper sensitivity setting. As a result of these findings, requirements were added to the UI standard (UL 167) to attempt to minimize these problem areas. Specifically, these additions included 1) a stability test (detector operation under varying temperature, humidity, air velocity, and barometric pressure), 2) requirements for the capability for measuring or monitoring the sensitivity of detectors while installed, and 3) requirements for the inclusion of a technical bulletin containing specific guidelines for detector installation.

As in the study by Fry, the UI study did not take into account the numbers of detectors in the system nor the age of the detectors. The UL study also did not report the numbers of alarms to real fires reported by the systems studied. Thus, false-to-real alarm ratios could not be computed for the UL survey.

\subsection{Review of Code Requirements for smoke Detectors in Health Care Facilities}

The primary U.S. standard which establishes the fire detection system requirements for health care facilities is the National Fire Protection Association (NFPA) Standard No. 101, known as the Life safety Code [3]. Chapter 10 of this code specifically deals with health care facilities and, although this is a voluntary standard, the majority of state and local building codes pattern their requirements for health care facilities after the requirements contained there.

The Life Safety Code was first printed by the NFPA in 1927 as the Building Exits Code. The 1963 edition did not mention the use of smoke detectors in health care facilities specifically, but allowed stairway, smoke stop and horizontal exit doors to stand open if arranged to close on actuation of an automatic fire detection or sprinkler system. The code was revised and retitled the Life safety Code in 1966, with this and all subsequent editions containing some requirements for smoke detectors in health care facilities. The 1966 edition requirement was similar to the 1963 requirement except that stairway doors were no longer permitted to stand open and the smoke stop and horizontal exit doors were to be controlled by a smoke detection system, with smoke detectors installed at the door or a total sprinkler system. The 1970 and 1973 codes contained similar requirements for door closer applications, adding an allowance for door closing on actuation of a manual fire alarm system. In addition, the 1973 code specified that an approved smoke detection system be installed in all corridors of new hospitals, nursing homes, and residential-custodial care facilities. The only exception was that, if smoke detectors were installed in patient rooms and local detectors were also provided at smoke partitions, then the detectors in the corridors were not required. The 1976 (current) edition of NFPA 101 contains the same smoke detector requirements as the 1973 edition except that the requirement for detectors in corridors of new hospitals was dropped.

The Life safety Code is structured as an occupancy code. That is, each chapter of the code, covering a different type of occupancy, includes general requirements for the types of fire protection measures to be taken in that occupancy. Specific system installation and maintenance requirements are included in other NFPA standards and referenced in NFPA 101 . Thus, NFPA 
101, Chapter 10 references NFPA Standard 72E (Automatic Fire Detectors) [4], which contains the specific installation guidelines for the smoke detectors required by that chapter. Standard $72 \mathrm{E}$ then contains more specific information, such as maximum and minimum ambient temperatures in spaces where detectors are to be installed, and spacing considerations as a function of such parameters as type of ceiling construction (e.g., smooth, beamed, sloped, etc.). However, with regard to maintenance and testing of detectors, Standard 72E suggests only that the manufacturers' instructions be followed. Most smoke detector manufacturers suggest annual cleaning as a minimum in normal environments and semiannual to annual testing.

The recommended cleaning procedures for many of the early smoke detector designs were complex. They often involved partial disassembly of the detector head and cleaning of internal parts with soap and water, or alcohol. In more recent years, these procedures are recommended only for detectors installed in extremely dusty environments. In more normal environments, most manufacturers suggest that an annual vacuuming is sufficient.

There is much more variation among different manufacturers in the recommended procedures for testing detectors than there is for periodic cleaning. Some detectors include built-in test features which mechanically or electrically simulate smoke within the detector. If the test feature is operated and the detector alarms, it is assumed that the detector circuitry is functional and that the sensitivity setting is correct. Other manufacturers provide sensitivity test meters, or terminals for connection of ordinary electrical meters, along with some type of correlation between the meter reading and the detector sensitivity. As part of their testing and approval procedures, UL determines that these various sensitivity measurement techniques operate as intended.

\section{SURVEY METHOD}

\subsection{Sampling and Data Collection}

The Health Care Financial Administration (HCFA), as part of the administration of federal Medicaid and Medicare funds, conducts an annual life safety survey of health care facilities receiving Medicaid and Medicare funding. This survey is conducted on a state-by-state basis on contract with the state health agency in each of the 50 states. In some states, the actual survey is conducted by the state fire marshal's office, and in other states by special inspection groups in health departments. The HCFA pays the contracting state agency for the time and travel cost associated with conducting the surveys. Contact was made with HCFA to determine if they would be amenable to modifying their normal survey form or including an addendum to the form to gather the desired data on smoke detectors. They responded favorably to including an addendum to their form in selected states. Since HHS divides the United States into 10 geographical regions for administrative purposes, it was then decided to prepare a one page survey form and to survey 10 states, hopefully one from each region. Due to administrative problems, only eight states were actually surveyed, with one of these eight returning the forms too late for inclusion in this report.

It was considered desirable to survey only states in each region in which the life safety survey is conducted by the state fire marshal's office since state fire marshal personnel should be more familiar with fire detectors and alarm systems than personnel in other state agencies. A list was received from HCFA showing the breakdown of the 50 states by region and those states where the HCFA survey is conducted by the state fire marshal's offices (table 1). In at least two states in each region except I and II the state fire marshal's office conducts the survey. Regions I and II which have none, were not surveyed. 
The data collection phase of the program was implemented in the spring of 1977 when copies of the form were submitted to HCFA. Forms were then distributed to the HCFA regional offices in regions III through $x$ and then to the state fire marshal's offices in the selected states along with the normal HCFA survey form. The state fire marshal's office then completed both forms on the annual visit to each health care facility receiving Medicare or Medicaid funds within their respective states. Upon completion, the forms were returned to HCFA where they were separated and the addendum form forwarded to NBS. Since each health care facility is visited once per calendar year, the NBS detector survey forms were included as an addendum to the inspection forms for the 12 months during which all facilities within a given state should have been visited. The last of the survey forms were received at NBS in the summer of 1978.

\subsection{Survey Form}

Two principal considerations influenced the design of the survey form. First, it was necessary to restrict the survey form to one page (including directions), and with a limited number of questions that could be completed quickly. Speed of completion dictated that narrative-type answers be minimized. Second, the questions required structuring in a manner which was compatible with the computer program which was to be used in analyzing the responses (OMNITAB $[5,6])$. Based on these considerations, the final form (figure 1) was developed. The data requested were limited to 10 questions plus space for an optional narrative. Check-off boxes were used wherever possible to limit responses to a reasonable number of categories which could be coded for analysis.

From the responses on the manufacturer and detector model number (survey form questions 1 and 2) the type of the detector (ionization, photoelectric, single-station residential, etc.) could be determined. The type of facility (question 3) was requested because the operating environment of the detectors may be significantly different between hospitals and nursing homes.

Questions 4 and 5 requested the total number of detectors and the approximate time in service. This information provided a means to normalize the false alarm data by the size of the system and its age. Question 6 requested the distribution of the total number of detectors by location and the numbers of actual and false alarms over the last five years or less, again by location.

Questions 7 and 8 dealt with the frequency and method of cleaning the smoke detectors, while questions 9 and 10 addressed the frequency and method of testing. It was hoped that this information, when compared with the false alarm information requested in question 6 , might indicate whether certain methods of cleaning or testing, or certain frequencies of cleaning or testing influence the rate of false alarms received.

\subsection{Data Analysis Technique}

As the survey forms were received at NBS, they were manually sorted to remove those forms that were inccrrectly completed. In some cases (for example, where all answers were completed except for the manufacturer's name but which could be inferred from the model number provided) a few of the incomplete forms were salvaged. The responses to each question on the Iorm were then manually recorded so that each response could be categorized. For example, all responses to question 3 (detector location) were tabulated and the eight most frequently given answers were each assigned a code number. All other responses to this question were assigned to a category identified as "other". In this way, a coding scheme was developed for the entire form. Table 2 shows the response codes for all of the survey questions except for manufacturer and model number. The manufacturer and model number coding are not identified in this report for privacy reasons. 
Since the exact number of facilities surveyed was considered much less important than having the responses separated by detector manufacturer and model number, it was decided that separate forms should be completed for each model detector within a specific facility. Therefore, the precise number of facilities surveyed cannot be determined.

\section{RESULTS}

\subsection{Data Received}

A total of 2371 survey forms were received, of which 1282 (54 percent) were unusable for various reasons. The remaining 1089 forms (46 percent) formed the basis for the analysis. Figure 2 shows the breakdown of forms received and the various reasons for a form being considered unusable. Incorrect model numbers (serial numbers, date codes, or model numbers which correspond to alarm bells, control panels, manual boxes, etc.) or no model number given accounted for over half (54 percent) of the unusable forms.

The 1089 valid forms were then manually sorted by manufacturer. This first sort gave a fairly large number of apparently different manufacturers, principally because a basic detector model may be sold not only by its manufacturer, but also by other companies, bearing their own name and model number. These private labelers are generally control panel manufacturers, distributors, or alarm installing companies.

Each of the companies which actually manufactures detectors was then contacted to request information concerning the correlation between the private label model numbers and their own model numbers. With this information, the data set was reduced to 13 basic detector manufacturers and their basic model numbers. Once this was done, the forms were again manually sorted by manufacturer. This process also revealed the existence of 80 duplicate forms which were deleted from the data base. As a result of this process, the final data base consisted of 1009 survey forms including responses on a total of 7323 detectors.

\subsection{Limitation of Results}

The 13 basic manufacturers of smoke detectors presently installed in the health care facilities surveyed accounted for more than 50 different smoke detector models. Table 3 shows the 13 manufacturers by letter code, the number of forms and percent of total number of forms (frequency) for each manufacturer, and the number of detectors and percent of total detectors for each manufacturer. One manufacturer (code $\mathrm{M}$ ) had only 38 detectors in a total of 6 systems: this is such a small percentage of the entire population that no conclusions can be based on the data obtained for this manufacturer's smoke detectors.

The validity of the data on several other manufacturers' models may also be marginal because of the small numbers of detectors involved and the relatively low numbers of false and real alarms reported. A major portion of the received forms reported no false nor real alarms. Even where a large number of detectors was encountered, the false and real alarm numbers reported came from only a small portion of the installed systems. As a result, numbers of false and real alarms may be based on only one person's memory, or the records of only one facility.

There are a number of possible explanations for this, such as (1) the detectors were properly designed and installed and are not subject to variations in ambient conditions which could cause false alarms, (2) detailed records on system operation were not kept and alarms occurred so infrequently that they were not remembered, or (3) there may have been a reluctance on 
the part of the health care facility administration to report false or real alarms to the state fire marshal's office for fear that changes in equipment or procedures would be required, costing the facility excessive time or money. Finally, rates of alarms to real fires are primarily a function of the low probability of a fire occurring, and as such can be used for little more than an indicator of the ratio of false alarms to real alarms.

Since there was no valid mechanism for taking these limitations into account, it was necessary to analyze the data as presented, keeping the limitations in mind as a source of uncertainty.

\section{DISCUSSION OF RESULTS}

The performance of a smoke detector can be affected by many variables, many of which could not be addressed from the limited data gathered in this survey. The variables which were considered were type of detector, location, and maintenance factors. Some of the factors which were not considered include unusual ambient conditions in which the detector must operate, possible exposure of the detector to physical damage, and the reliability of interconnection systems, wiring, or individual detector components.

Since the probability of a false alarm in a fire alarm system containing many smoke detectors would be expected to increase with increasing numbers of connected detectors and increasing time in service, the numbers of false and real alarms reported were normalized by these two values to provide false and real alarm frequency figures for comparing systems of different age and size. False alarm frequency is therefore defined here as the number of reported false alarms divided by the product of the number of devices in the system and the number of years in service. This is comparable to the calculation of failure rate in electronic components expressed in terms of failures per device hours in service. Thus, if a detector model exhibited a false alarm rate of 0.1 false alarms per device year in service, an installed system consisting of 10 detectors of this model would give an average of one false alarm per year. Similarly, a system of 100 detectors of this model would average 10 false alarms per year.

\subsection{Distribution of Alarms by Manufacturer and Model}

In the entire population of surveyed data, 1088 false alarms and 78 actual alarms were reported. This results in a ratio of false to real alarms for smoke detectors installed in health care facilities of approximately 14 to 1 , which is the same false to real alarm ratio found by Fry [1] for smoke detection systems in general.

The false alarm frequency for the entire population of detectors was found to be $4.4 \times 10^{-2}$ false alarms per device year in service. That is, any smoke detection system of 100 detectors would be mathematically expected to give an average of 4.4 false alarms per year. The alarm frequency for real fires was found to be approximately one order of magnitude lower, or about $3.1 \times 10^{-3}$ real alarms per device year in service.

Detector performance for each of the 13 manufacturers, based on alarm frequency, is presented in table 4. Many of the frequencies appearing in this table may be unrepresentative (excessively high or low) as a result of a small sample of detectors and few reported alarms for certain manufacturers (as previously discussed for manufacturer M). It should also be noted that a few manufacturers stand out due to unusually low frequencies. In particular, manufacturer $E$ seems to have an exceptionally low false alarm rate but firm conclusions about manufacturer E's performance are not possible. On the one hand, there are few alarms reported ( 3 false and 1 real), the 
number of real alarms depending primarily on the very low probability of a fire occurring. On the other hand, due to the large number of detectors reported for this manufacturer (9.6 of total detectors) these alarm rates may have some statistical validity. The low false alarm rate may indeed indicate outstanding performance, or the low false and real alarm rates may merely reflect a lower average detector sensitivity.

Appendix table A2 summarizes the survey results by model number. Here, somewhat more variation is seen. The highest value by model is $47 \times 10^{-2}$ for manufacturer $\mathrm{H}$, model 1 . The lowest false alarm frequency is $0.13 \times 10^{-2}$ for manufacturer $E$, model 0 .

\subsection{Distribution of Alarms by Type of Detector}

Almost 71 percent of the total number of detectors in the survey were ionization-type detectors. Detectors from manufacturers $A, D$, and $K$ are photoelectric detectors and the rest are ionization type. Table 5 compares false and real alarm frequencies between the two types of detectors. This table indicates that the false alarm frequencies for ionization detectors are slightly less than those for photoelectric detectors and the real alarm frequency is slightly more. However, with the degree of uncertainty in the data, these slight differences are probably not significant. There is no evidence to suggest that there is any real difference in false or real alarm frequency between types of detector.

Analysis of the data by model number also revealed that 14 percent of the total number of detectors in the survey were of the single-station, battery-operated, residential type. It was discovered that almost all of these were installed in facilities located in one of the surveyed states under a state-sanctioned, temporary program to provide protection until fire detection systems can be installed. The yearly false alarm frequency for single-station detectors was $4.8 \times 10^{-2}$ with an average real alarm frequency of $3.7 \times 10^{-3}$. These figures are very similar to those reported for the entire population of detectors. The small variation in the alarm figures in table 5 and those for residential detectors given above seems to indicate that the probability of a smoke detection system false alarm is independent of whether the detector is ionization or photoelectric or whether it is a commercial or residential-type detector. Of course, commercial detection systems are preferred for their central supervision and alarm signaling features.

\subsection{Distribution of Data by Detector Location}

The largest percentage of the detectors in the sample ( 71.4 percent) were installed in corridors (table 6). These detectors consisted of both the open area and door closer types. Those installed in patient rooms accounted for almost 7 percent of the sample, second in rank order. Dining rooms were third, 2 percent of the sample.

It is interesting to note that the location of most detectors and the fact that the majority of the installations were made in 1973 and 1974 corresponds to the adoption of the detector requirements in the $1973 \mathrm{Life}$ Safety Code. This seems to indicate that the impact of NFPA 101 is substantial in health care facilities.

Table 7 shows the distribution of reported alarms by detector location. While corridor and patient room mounted detectors represented the vast majority of all detectors in the sample, their false alarm rates were among the lowest. Smoke detectors installed in laundry facilities, storage rooms, kitchens, and dining rooms had the highest false alarm rates by location. This might be expected since these are areas which would have greater extremes of ambient conditions and non-fire background sources. This would 
also indicate that smoke detectors are probably inappropriate for the protection of storage rooms, laundry facilities, and areas around kitchens. The important considerations with regard to the application of fire detectors in health care facilities will be covered in detail in a subsequent paper currently in preparation at NBS.

\subsection{Maintenance}

It is reasonable to assume that a fire detection system which is properly maintained will exhibit fewer false alarms than one which is not. To test the validity of this assumption, the false alarm rate was compared against the normal maintenance practices of cleaning and regular testing. Both the fequency and method employed for cleaning and testing were evaluated.

\subsubsection{Cleaning}

Table 8 shows the percent of total detectors cleaned by various methods. Table 9 gives the distribution of reported alarms as a function of cleaning method and frequency. Those detectors which were cleaned and maintained through a contracted service agreement resulted in a low false alarm frequency.

The survey indicates that a little more than 45 percent of the detector systems were never cleaned and that this same group of detectors exhibited the second lowest false alarm rate. While this might suggest that cleaning is not critical, it might also indicate that detectors which are not cleanea do not alarm because they have lost sensitivity. Unfortunately, the limited data obtained in this survey do not provide any basis for testing this hypothesis.

With regard to frequency of cleaning, the data seem to indicate that lower false alarm rates (neglecting detectors not cleaned for the reasons stated above) are obtained from the detectors which are cleaned more often. The rate of false alarms from detectors cleaned yearly was almost twice that for detectors cleaned monthly. While the rate of false alarms for detectors reported as cleaned only when they give trouble was the lowest, this category represented only $3-1 / 2$ percent of the detectors sampled, a number too small to draw valid conclusions.

\subsubsection{Testing}

Frequency of testing more clearly affects false alarm rate than does frequency of cleaning. That is, the lowest false alarm rate was observed in detectors tested monthly, with the false alarm rate increasing with decreasing frequency of testing (see table 10). The highest false alarm rate was observed in detectors which were never tested. The false alarm rate for those reported as occasionally tested was not computed as this represented only 0.3 percent of the detectors sampled. While testing should have no direct affect on rate of false alarms, it may be assumed that regular testing would identify detectors which appear to be inordinately sensitive or insensitive, permitting corrective action.

The data on method of testing indicates that the majority of all smoke detectors are tested using smoke from some source. A small number of respondents indicated that the detectors were tested by observing an operational light on the detector. This indicates a lack of understanding of the detector operation since the light on most detectors only indicates alarm or the fact that power is available. While one particular manufacturer states that the pulsing frequency of the light is a general indication of his detector's sensitivity, there is some doubt as to whether this is a valid indication. 


\section{SUMMARY OF FINDINGS}

The following summarizes the key points of the data analysis and presents general indications drawn from the survey data. It is important to keep in mind the limitations of the survey, particularly the relatively small sample size and the small number of detectors from which alarms were reported.

1. There were 13 major manufacturers of smoke detectors identified in the survey. From the data obtained in the survey it was not possible to demonstrate any meaningful difference in alarm frequency among these manufacturers.

2. An overall false alarm frequency of $4.4 \times 10^{-2}$ (alarms per device per year in service) and an overall real alarm frequency of $3.1 \times 10^{-3}$ (alarms per device per year in service) was found for smoke detectors installed in the health care facilities surveyed.

3. The false alarm to real alarm ratio was 14:1 for smoke detectors installed in the health care facilities surveyed.

4. There appeared to be no meaningful difference between ionization-type and photoelectric-type smoke detectors with regard to real alarm and false alarm frequencies reported in this survey.

5. Approximately 14 percent of the detectors presently installed in the health care facilities surveyed were of the single-station, batteryoperated, residential type. Almost all of these were installed in facilities located in only one of the states surveyed as a temporary method of protection until systems could be installed.

6. It appeared that the Life Safety Code (NFPA Standard No. 101) had a significant effect on the location and installation of smoke detectors in the health care facilities surveyed. Most detectors were located in the areas required by NFPA standard No. 101, namely corridors and patient rooms, and the majority of installations were made shortly after requirements were adopted in NFPA 101.

7. Basements, kitchens, laundry facilities, and storage rooms may expose detectors to environmental conditions that can induce performance problems, as suggested by the higher false alarm rates for detectors in these locations.

8. It was found that many facilities were not complying with recommended maintenance procedures. However, it was also found that when detectors were maintained, they were maintained according to manufacturers' instructions and recommended practices.

9. For the detectors in the facilities surveyed, 46 percent of the forms reported detectors were never cleaned and only 30 percent reported detectors cleaned once a year or more frequently.

10. The predominant cleaning methods reported were by compressed air, alcohol wash, or vacuuming.

11. Over 88 percent of the forms reported detectors were tested once a year or more frequently, with 55 percent of the forms reporting detectors tested monthly.

12. The predominant testing method was by the use of some type of smoke.

13. Detectors tested more frequently had lower false alarm rates than those tested less frequently or never tested. 
The data obtained by this survey provide valuable information on the current performance of smoke detectors in health care facilities and the effects of regular maintenance procedures on this performance. But due to the rather small number of responses, and especially the very small number of reported alarms, the conclusions drawn from the data must only be considered as indications and not as definitive facts.

If a systematic program of keeping and collecting detailed records on alarms, testing and maintenance of detectors and other fire alarm system components is instituted, a more accurate picture of system performance under field conditions could be obtained. In this way problem areas can be identified and changes to approval procedures and application practices can be initiated which will improve the performance and reliability of these systems.

\section{REFERENCES}

[1] Fry, J. F., The Problems of False Alarms from Fire Detection Systems. In Problems in Automatic Fire Detection, Aachen Inst., (October 4-6, 1971).

[2] Underwriters Laboratories Inc., Ionization Type Smoke Detector Field Study-False Alarm History Prior to April 1969, presented at the meeting of Underwriters Laboratories Inc., Northbrook, IL (April 10, 1969).

[3] Life Safety Code, NFPA 101, National Fire Protection Association, 470 Atlantic Ave., Boston, MA (1963, 1966, 1967, 1970, 1973, 1976).

[4] Automatic Fire Detectors, NFPA 72E, National Fire Protection Association, 470 Atlantic Ave., Boston, MA (1978).

[5] Hogben, D., Peavy S. T. and Varner, R. N., OMNITAB II User's Reference Manual, Nat. Bur. Stand. (U.S.), Tech. Note 552, (October 1971).

[6] Hogben, D. and Peavy, S. T., OMNITAB II User's Reference Manual 1977 Supplement, Nat. Bur. Stand. (U.S.), NBSIR 77-1276 (July 1977). 
INSTRUCTIONS: This form should be completed on each detector model installed in a health care facility. This would include open area detectors, door closer detectors, and detectors in HVAC duct work. The information gathered will be used to form a data base by which the past performance of smoke detectors in health care facilities can be evaluated.

A SEPARATE FORM SHOULD BE COMPLETED FOR EACH DETECTOR MODEL USED IN THE BUILDING.

Block 1 - Smoke detectors to be surveyed include ionization chamber and photoelectric types used for open area, duct, and door closer applications.

2 - The manufacturer and model no. is usually on the back of the detector if not available from the building management.

4 - Enter total number of detectors of indicated manufacturer and model no. used in this facility.

6 - This data should include detectors of the model indicated in block 2 which are installed in each area. If false and real alarm data is not available by area of occurrence, estimates should be made or totals included and indicated as such. (A false alarm is any alarm where no fire is present.)

$7,8,9$ - Frequency and method of cleaning and testing should be those

\& 10 figures actually done, not what is planned or recommended.

1. Detector Manufacturer

2. Detector Model No.

3. Type of Facility

Hospital $\square$ Nursing Homes

Other (specify):

Years

6. Detector Location | Number | No. of Alarms

of

From Actual Fires

No. of False Alarms

Patient Room

Corridor

other (specify)

7. Frequency of Cleaning Detectors

$\square$ Monthly. $\square$ Yearly $\square$ Never

other (specify):

9. Frequency of Testing Detectors

$\square$ Monthly $\square$ Yearly $\square$ Never

$\square$ other (specify):

11. Additional Comments on the Operation of the Detectors (May include comments by facility personnel concerning effectiveness of the system or general problems encountered)

Comments continued on reverse Signature of Person Completing Form Organization Date 


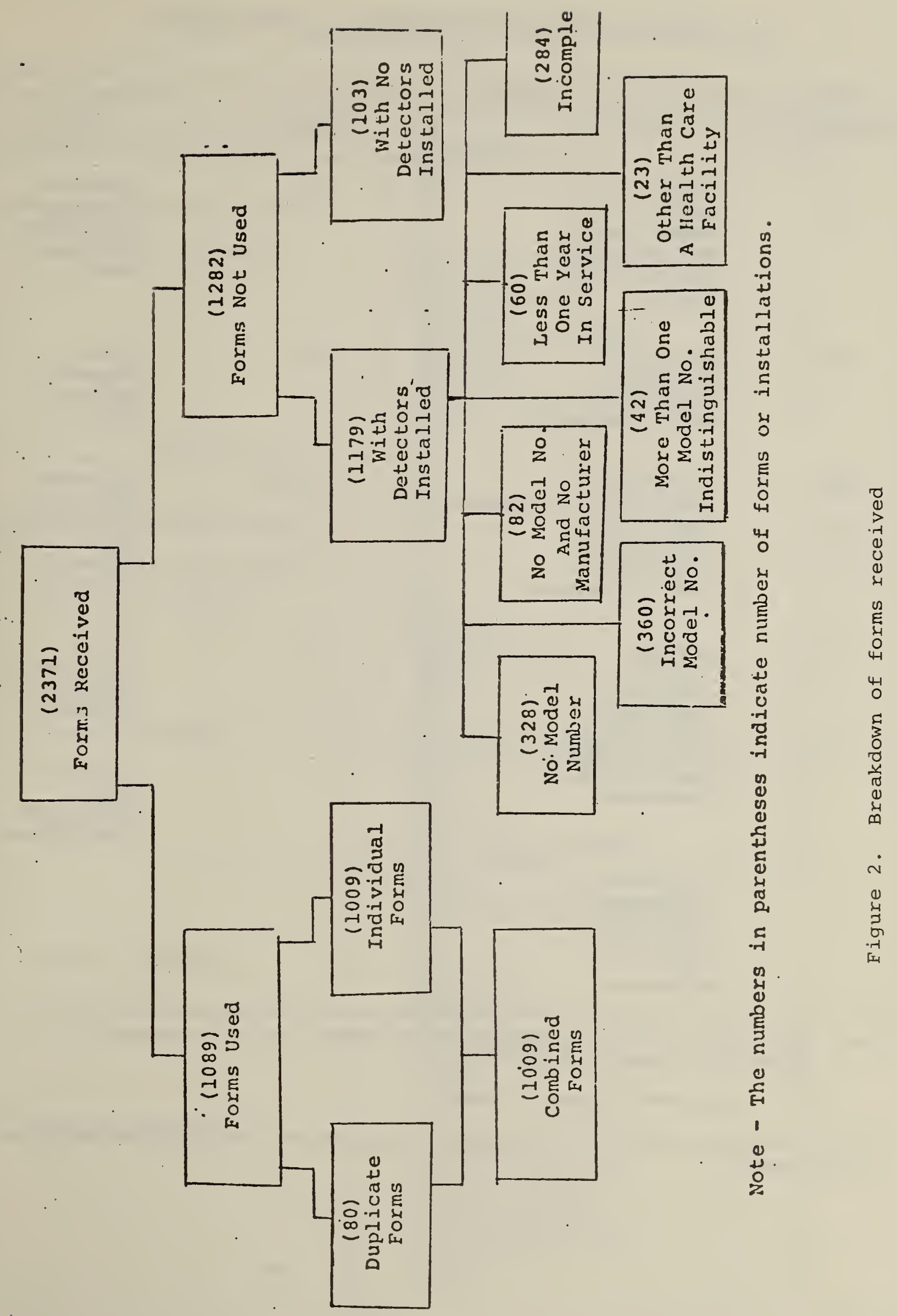


Table 1. Regional breakdown of fifty states

\begin{tabular}{|c|c|c|c|}
\hline Region & state & Region & State \\
\hline I & $\begin{array}{l}\text { Connecticut } \\
\text { Maine } \\
\text { Massachusetts } \\
\text { New Hampshire } \\
\text { Rhode Island } \\
\text { Vermont }\end{array}$ & VI & $\begin{array}{l}\text { Arkansas } \\
\text { (Louisiana) } \\
\text { New Mexico } \\
\text { (Oklahoma) } \\
\text { Texas }\end{array}$ \\
\hline II & $\begin{array}{l}\text { New Jersey } \\
\text { New York } \\
\text { Puerto Rico } \\
\text { Virgin Islands }\end{array}$ & VII & $\begin{array}{l}\text { (Iowa) } \\
\text { (Kansas)* } \\
\text { (Nebraska) } \\
\text { Missouri }\end{array}$ \\
\hline III & $\begin{array}{l}\text { (Delaware) } \\
\text { (District of Columbia) } \\
\text { (Maryland)* } \\
\text { Pennsylvania } \\
\text { (Virginia) } \\
\text { (West Virginia) }\end{array}$ & VIII & $\begin{array}{l}\text { Colorado } \\
\text { (Montana) } \\
\text { (North Dakota) } \\
\text { South Dakota } \\
\text { (Utah)* } \\
\text { (Wyoming) }\end{array}$ \\
\hline IV & $\begin{array}{l}\text { Alabama } \\
\text { Florida } \\
\text { (Georgia)* } \\
\text { (Kentucky) } \\
\text { Mississippi } \\
\text { North Carolina } \\
\text { South Carolina } \\
\text { Tennessee }\end{array}$ & IX & $\begin{array}{l}\text { Arizona } \\
\text { (California) * } \\
\text { (Hawaii) } \\
\text { (Nevada) } \\
\text { (Alaska) } \\
\text { Idaho } \\
\text { (Oregon) * } \\
\text { (Washington) * }\end{array}$ \\
\hline V & $\begin{array}{l}\text { (Indiana) } \\
\text { (Illinois) } \\
\text { (Minnesota)** } \\
\text { (Michigan) } \\
\text { Ohio } \\
\text { Wisconsin }\end{array}$ & & \\
\hline
\end{tabular}

Note: Parenthesis indicate states where inspection is conducted by state fire marshal's office.

Star indicates states surveyed.

**State was surveyed but the data was received too late for inclusion in this report. 
Table 2. Coded responses to the survey questions

\begin{tabular}{|c|c|c|}
\hline Question & Response & Code \\
\hline 1. Type of Facility & $\begin{array}{l}\text { Hospital } \\
\text { Nursing Home }\end{array}$ & $\frac{1}{2}$ \\
\hline 2. Time in Service (years) & - & $1,2,3 \ldots$ \\
\hline 3. Location of Detector & $\begin{array}{l}\text { Patient Room } \\
\text { Corridor } \\
\text { Storage Room } \\
\text { Basement } \\
\text { Laundry Facilities } \\
\text { Duct Work } \\
\text { Kitchen } \\
\text { Dining Room } \\
\text { Other }\end{array}$ & $\begin{array}{l}1 \\
2 \\
3 \\
4 \\
5 \\
6 \\
7 \\
8 \\
9\end{array}$ \\
\hline $\begin{array}{l}\text { 4. Number of Detectors in } \\
\text { Location }\end{array}$ & - & $1,2,3 \ldots$ \\
\hline 5. Number of Actual Alarms & - & $0,1,2,3 \ldots$ \\
\hline 6. Number of False Alarms & - & $0,1,2,3 \ldots$ \\
\hline 7. Cleaning Frequency & $\begin{array}{l}\text { Monthly } \\
\text { Yearly } \\
\text { When Trouble } \\
\text { Never } \\
\text { Other }\end{array}$ & $\begin{array}{l}1 \\
2 \\
3 \\
8 \\
9\end{array}$ \\
\hline 8. Cleaning Method & $\begin{array}{l}\text { Vacuuming } \\
\text { Dusting } \\
\text { Water } \\
\text { Air } \\
\text { Alcohol } \\
\text { Service Contracted } \\
\text { Not Cleaned } \\
\text { Other } \\
\text { Combination of Dusting } \\
\text { and Air }\end{array}$ & $\begin{array}{l}1 \\
2 \\
3 \\
4 \\
5 \\
6 \\
8 \\
9 \\
7\end{array}$ \\
\hline 9. Testing Frequency & $\begin{array}{l}\text { Monthly } \\
\text { Quarterly } \\
\text { Semiannually } \\
\text { Yearly } \\
\text { Occasionally } \\
\text { Never } \\
\text { Other }\end{array}$ & $\begin{array}{l}1 \\
2 \\
3 \\
4 \\
5 \\
8 \\
9\end{array}$ \\
\hline 10. Testing Method & $\begin{array}{l}\text { Smoke } \\
\text { Cigarettes } \\
\text { Burning Materials } \\
\text { Magnetic Device } \\
\text { Method Unknown } \\
\text { Operational Light } \\
\text { Not Tested } \\
\text { Other }\end{array}$ & $\begin{array}{l}1 \\
2 \\
3 \\
4 \\
5 \\
7 \\
8 \\
9\end{array}$ \\
\hline
\end{tabular}


Table 3. Number of forms and total number of detectors by manufacturer

\begin{tabular}{|c|c|c|c|c|}
\hline \multirow{2}{*}{$\frac{\text { Manufacturer }}{\text { Code }}$} & \multicolumn{2}{|c|}{ Forms } & \multicolumn{2}{|c|}{ Detectors } \\
\hline & Number & Percent & Number & Percent \\
\hline$A$ & 243 & 24.1 & 1376 & 18.8 \\
\hline B & 125 & 12.4 & 796 & 10.9 \\
\hline C & 108 & 10.7 & 894 & 12.2 \\
\hline D & 105 & 10.4 & 631 & 8.6 \\
\hline$E$ & 89 & 8.8 & 704 & 9.6 \\
\hline F & 76 & 7.5 & 551 & 7.5 \\
\hline G & 67 & 6.6 & 966 & 13.2 \\
\hline $\mathrm{H}$ & 64 & 6.3 & 223 & 3.0 \\
\hline I & 53 & 5.3 & 407 & 5.6 \\
\hline $\mathrm{J}$ & 31 & 3.1 & 464 & 6.3 \\
\hline $\mathrm{K}$ & 26 & 2.6 & 125 & 1.7 \\
\hline L & 16 & 1.6 & 148 & 2.0 \\
\hline M & 6 & 0.6 & 38 & 0.5 \\
\hline Totals & 1009 & 100.0 & 7323 & 100.0 \\
\hline
\end{tabular}


Table 4. Summary of false and real alarm frequency by manufacturer

\begin{tabular}{|c|c|c|c|c|c|}
\hline $\begin{array}{c}\text { Manufacturer } \\
\text { : Code }\end{array}$ & $\begin{array}{l}\text { Alar } \\
\text { False }\end{array}$ & $\begin{array}{l}\text { ns } \\
\text { Real }\end{array}$ & $\begin{array}{l}\text { Device } \\
\text { Yrs } \\
\text { In Service }\end{array}$ & $\begin{array}{c}\text { False Alarms Per } \\
\text { Device } \operatorname{Ir} \text { in } \\
\text { Service } x\left(10^{-2}\right)\end{array}$ & $\begin{array}{l}\text { Real Alarms Per } \\
\text { Device } \operatorname{Yr} \text { in } \\
\text { Service } x\left(10^{-3}\right)\end{array}$ \\
\hline $\mathrm{A}$ & 115 & 15 & 5052.0 & 2.3 & 3.0 \\
\hline B & 50 & 4 & 2827.0 & 1.8 & 1.4 * \\
\hline C & 243 & 14 & 3277.0 & 7.4 & 4.3 \\
\hline D & 164 & 10 & 1787.0 & 9.2 & 5.6 \\
\hline $\mathrm{E}$ & 3 & 1 & 2311.5 & $0.1 *$ & $0.4 *$ \\
\hline$F$ & 55 & 4 & 1927.5 & 2.9 & $2.1 *$ \\
\hline G & 151. & 13 & 3507.0 & 4.3 & 3.7 \\
\hline $\mathrm{H}$ & 67 & 4 & 851.0 & 7.9 & $4.7 *$ \\
\hline I & 109 & 1 & 1278.0 & 8.5 & $0.8 *$ \\
\hline $\mathrm{J}$ & 69 & 5 & 1009.0 & 6.8 & $5.0 *$ \\
\hline K & 26 & 2 & 527.5 & 4.9 & $3.8 *$ \\
\hline L & 32 & 2 & 374.5 & 8.6 & $5.3 *$ \\
\hline M & 4 & 3 & 178.0 & $2.3 *$ & $16.9 *$ \\
\hline Totals & 1088 & 78 & $24,907.0$ & 4.4 & 3.1 \\
\hline
\end{tabular}

*These figures, which provide some additional information, are not a good estimate of the true performance because of the low number of alarms. 
Table 5. Summary of false and real alarm frequency by type of detector

\begin{tabular}{|c|c|c|c|c|c|}
\hline \multicolumn{3}{|c|}{$\begin{array}{l}\text { Ionization Type } \\
\text { Manufacturers }\end{array}$} & \multicolumn{3}{|c|}{$\begin{array}{c}\text { Photoelectric Type } \\
\text { Manufacturers }\end{array}$} \\
\hline $\begin{array}{l}\text { MFR } \\
\text { Code }\end{array}$ & $\begin{array}{c}\text { Real Alarm } \\
\text { Frequencies } \\
\text { x10-3 }\end{array}$ & $\begin{array}{c}\text { False Alarm } \\
\text { Frequencies } \\
\times 10^{-2}\end{array}$ & $\begin{array}{l}\text { MFR } \\
\text { Code }\end{array}$ & $\begin{array}{c}\text { Real Alarm } \\
\text { Frequencies } \\
\times 10^{-3}\end{array}$ & $\begin{array}{c}\text { False Alarm } \\
\text { Frequencies } \\
\times 10^{-2}\end{array}$ \\
\hline B & 1.4 * & 1.8 & A & 3.0 & $2.3 *$ \\
\hline C & 4.3 & 7.4 & D & 5.6 & 9.2 \\
\hline$E$ & 0.4 * & $0.1 *$ & $\mathrm{~K}$ & $3.8 *$ & 4.9 \\
\hline$F$ & $2.1 *$ & 2.9 & & & \\
\hline G & 3.7 & 4.3 & & & \\
\hline $\mathrm{H}$ & $4.7 *$ & 7.9 & & & \\
\hline$I$ & $0.8 *$ & 8.5 & & & \\
\hline $\mathrm{J}$ & $5.0 *$ & 6.8 & & & \\
\hline L & $5.3 *$ & 8.6 & & & \\
\hline M & $16.9 *$ & 2.3 & & & \\
\hline AVG & $4.46 \times 10^{-3}$ & $5.06 \times 10^{-2}$ & AVG & $4.1 \times 10^{-3}$ & $5.47 \times 10^{-2}$ \\
\hline
\end{tabular}

*These figures, which provide some additional information, are not a good estimate of the true performance because of the low number of alarms.

Table 6. Distribution of detectors by lccation

\begin{tabular}{|l|c|c|}
\hline \multicolumn{1}{|c|}{ Location } & Number of Detectors & Percent of Detectors \\
\hline Patient Room & 1581 & 6.6 \\
Corridor & 5228 & 79.2 \\
Storage Room & 11 & 0.5 \\
Basement & 9 & 0.4 \\
Laundry Facilities & 8 & 0.8 \\
Ductwork & 91 & 1.4 \\
Kitchen & 11 & 0.8 \\
Dining Room & 39 & 2.0 \\
Other & 345 & 8.3 \\
\hline
\end{tabular}




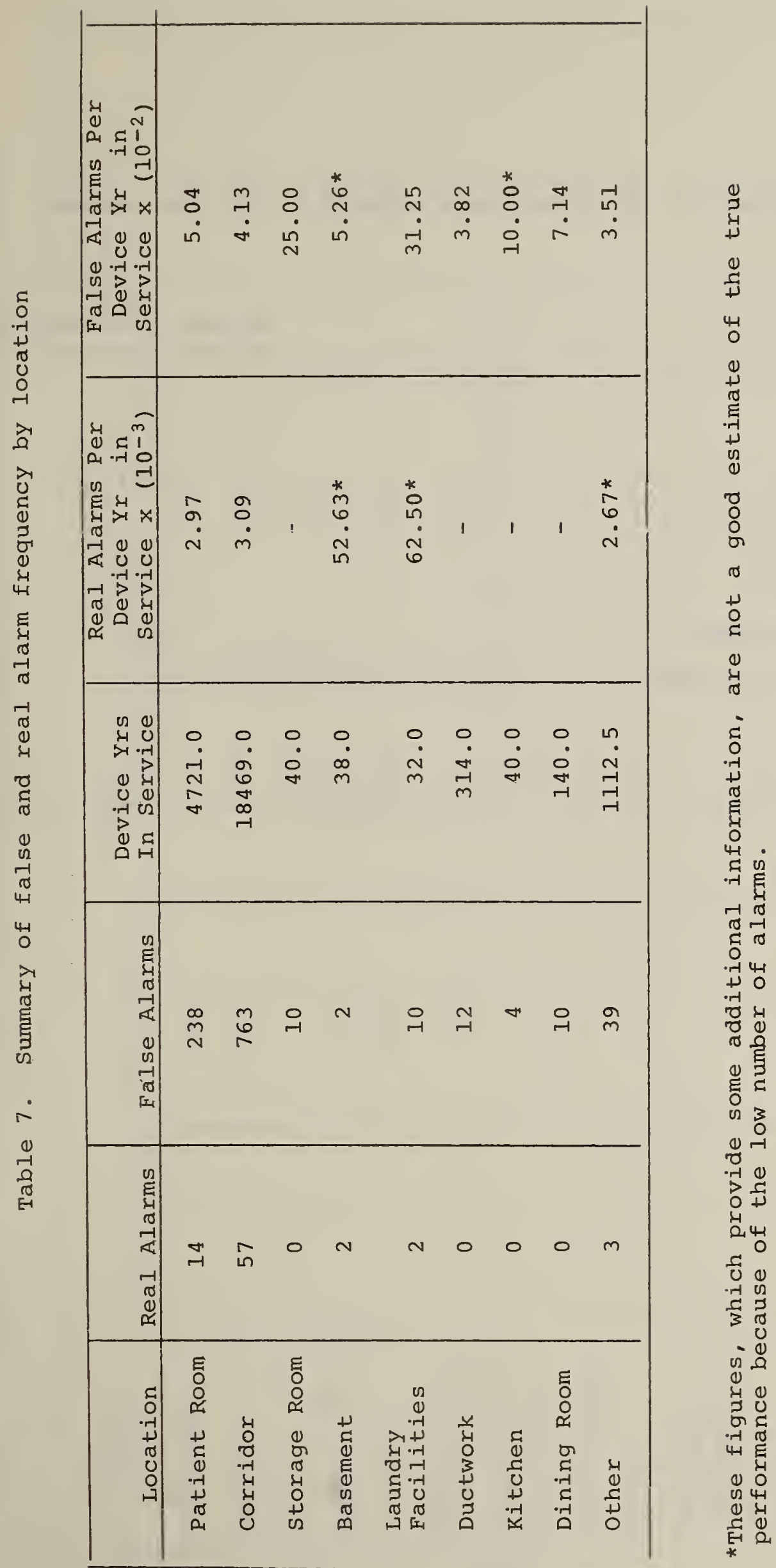


Table 8. Percent of total detectors cleaned by various methods

\begin{tabular}{|c|c|}
\hline Cleaning Method & Percent of Detectors \\
\hline 1. Vacuum & 8.1 \\
\hline 2. Dusting & 5.3 \\
\hline 3. Water (wash) & 0.4 \\
\hline 4. Compressed Air & 10.6 \\
\hline 5. Alcohol (wash) & 13.3 \\
\hline 6. Service Contracted & 10.9 \\
\hline 7. Combination of 2 and 4 & 0.4 \\
\hline 8. Not Cleaned & 45.7 \\
\hline 9. Other & 5.4 \\
\hline
\end{tabular}




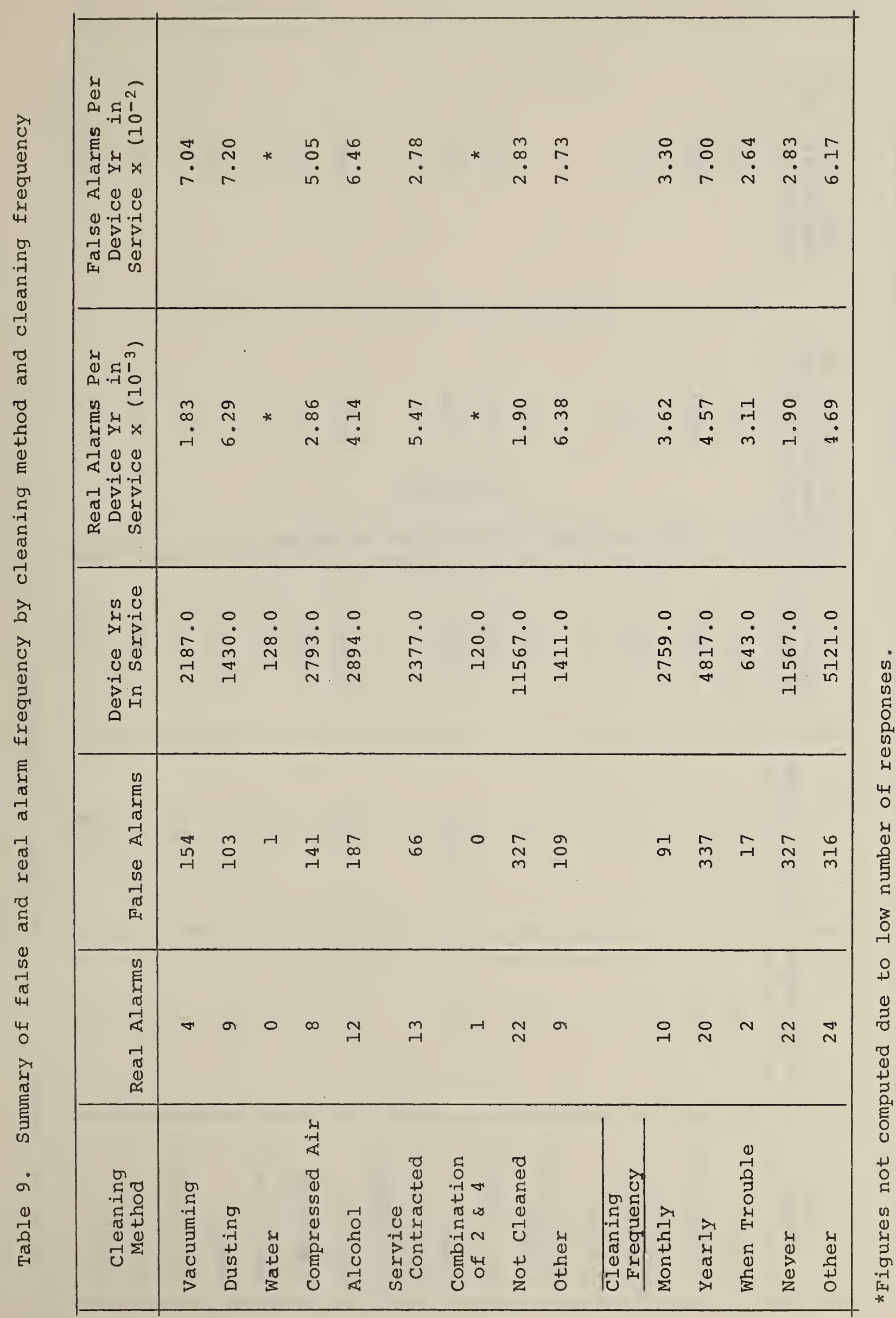




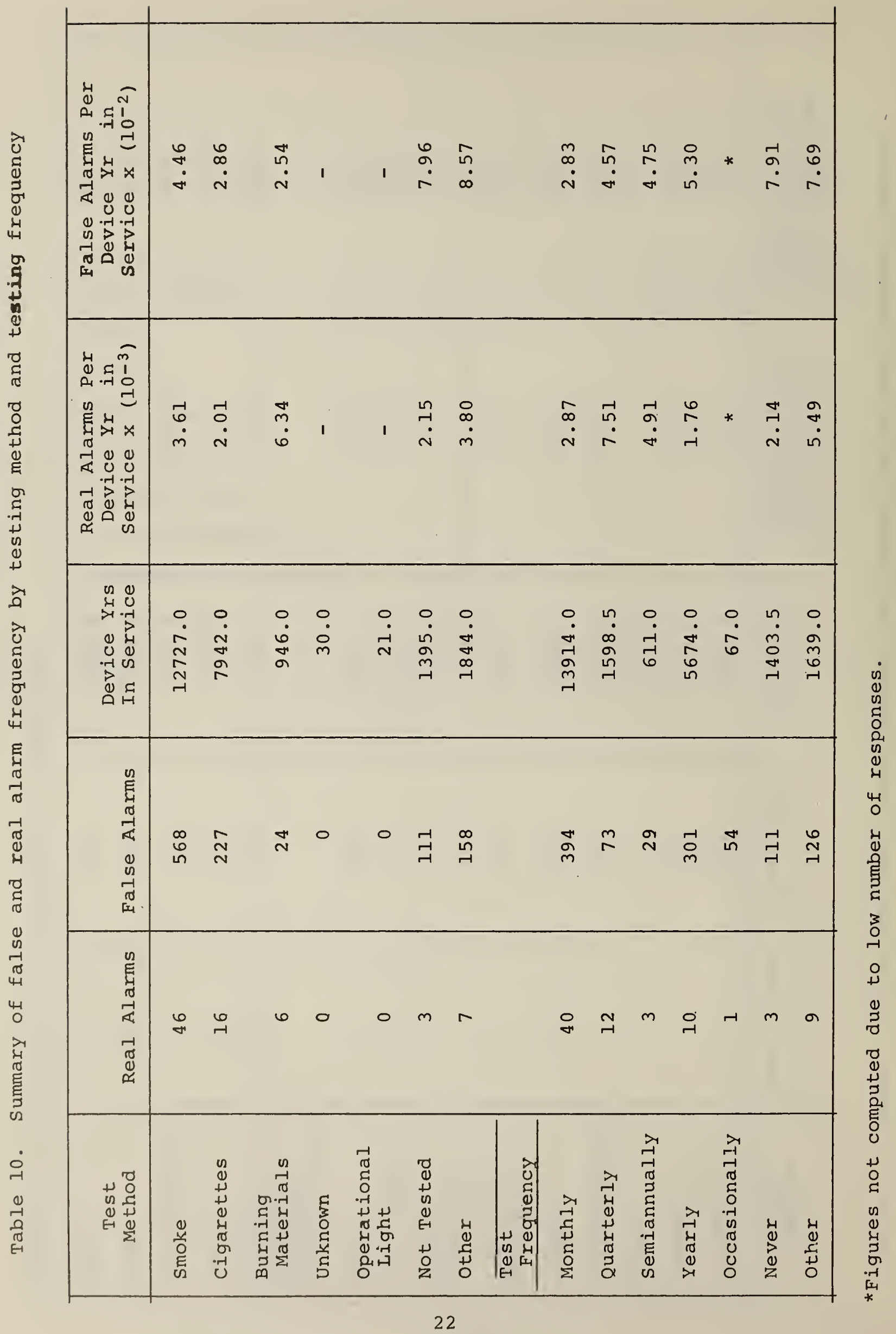


APPENDIX A

A COMPLETE TABULATION OF THE RESULTS FROM THE SURVEY QUESTIONS 



\begin{tabular}{|c|c|c|c|c|c|c|c|c|c|c|c|c|c|}
\hline 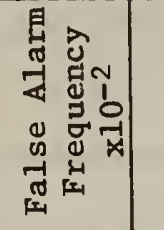 & $\dot{n}$ & $\stackrel{\infty}{-1}$ & $\stackrel{v}{\sim}$ & $\stackrel{v}{a}$ & $\ddot{0}$ & if & $\ddot{j}$ & $\stackrel{9}{r}$ & $\stackrel{n}{\infty}$ & $\stackrel{\infty}{\dot{0}}$ & g & $\stackrel{0}{\infty}$ & $\ddot{n}$ \\
\hline 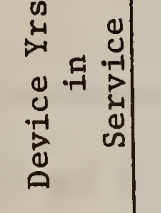 & $\begin{array}{l}0 \\
\text { กี } \\
\text { กิ }\end{array}$ & $\begin{array}{l}0 \\
\stackrel{i}{N} \\
\infty \\
\text { N }\end{array}$ & $\frac{0}{\tilde{N}}$ & $\begin{array}{c}0 \\
0 \\
\infty \\
-1\end{array}$ & $\begin{array}{l}\text { n } \\
\stackrel{-}{-1} \\
\stackrel{n}{N}\end{array}$ & $\stackrel{n}{\stackrel{n}{N}}$ & $\begin{array}{l}0 \\
\dot{0} \\
\stackrel{1}{m}\end{array}$ & $\begin{array}{c}0 \\
\dot{-1} \\
\infty \\
\infty\end{array}$ & $\begin{array}{l}0 \\
\infty \\
\\
\end{array}$ & $\begin{array}{l}0 \\
\dot{8} \\
8 \\
0\end{array}$ & $\stackrel{n}{\tilde{n}}$ & $\dddot{n}$ & 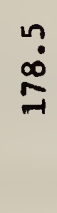 \\
\hline 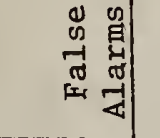 & $\stackrel{n}{\beth}$ & in & $\stackrel{m}{\sim}$ & $\underset{-1}{\Delta}$ & $m$ & in & ન્ન & $\hat{0}$ & $\stackrel{9}{\circ}$ & बู่ & $\stackrel{\sim}{\sim}$ & స్ & + \\
\hline 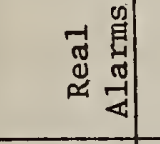 & $\stackrel{\sim}{\sim}$ & $\checkmark$ & न & 윅 & -1 & $\checkmark$ & $\stackrel{m}{r}$ & $\checkmark$ & -1 & in & $N$ & $N$ & $m$ \\
\hline 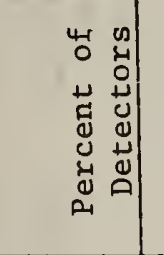 & $\begin{array}{l}\infty \\
\dot{\infty} \\
\stackrel{-1}{0}\end{array}$ & $\begin{array}{l}9 \\
0 \\
0\end{array}$ & $\underset{\sim}{\sim}$ & $\begin{array}{l}0 \\
\infty\end{array}$ & $\begin{array}{l}0 \\
a\end{array}$ & $\stackrel{\text { n }}{i}$ & $\stackrel{r}{\ddot{r}}$ & $\stackrel{0}{\dot{n}}$ & $\begin{array}{l}0 \\
\text { in }\end{array}$ & ? & $\tilde{r}$ & ì & $\ddot{0}$ \\
\hline 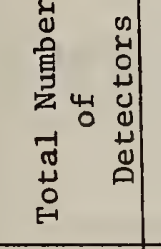 & $\stackrel{0}{n}$ & $\stackrel{\circ}{\pi}$ & పे & $\overrightarrow{\tilde{\vartheta}}$ & 옹 & 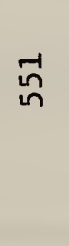 & 号 & $\stackrel{\tilde{N}}{N}$ & ơ & \begin{tabular}{l} 
đ̛ \\
\multirow{J}{*}{}
\end{tabular} & 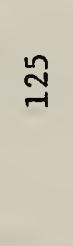 & $\stackrel{\infty}{\underset{1}{1}}$ & $\stackrel{\infty}{m}$ \\
\hline 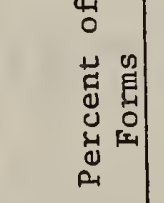 & $\stackrel{+}{\dot{\sim}}$ & $\underset{\sim}{\vec{r}}$ & r & $\stackrel{+}{\dot{0}}$ & $\begin{array}{l}\infty \\
\infty\end{array}$ & $\stackrel{n}{r}$ & $\ddot{0}$ & $\ddot{0}$ & m & $\dot{r}$ & $\stackrel{0}{\dot{\sim}}$ & $\stackrel{0}{-i}$ & $\stackrel{\varphi}{0}$ \\
\hline 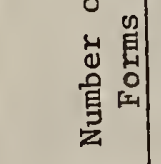 & $\stackrel{\text { I }}{\sim}$ & $\stackrel{\Perp n}{\sim}$ & $\stackrel{\infty}{\circ}$ & $\stackrel{\text { ڤ̊ }}{\circ}$ & ஓి & $\stackrel{2}{2}$ & $\widehat{6}$ & ปै & in & $\vec{m}$ & $\stackrel{\sim}{\sim}$ & $\underset{-1}{6}$ & 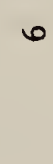 \\
\hline 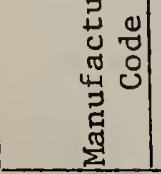 & $\varangle$ & ఐ & 0 & $\theta$ & $\Leftrightarrow$ & Is & 0 & 工 & $H$ & $\neg$ & $\square$ & $\mu$ & $\Sigma$ \\
\hline
\end{tabular}




\begin{tabular}{|c|c|c|c|c|c|c|c|}
\hline 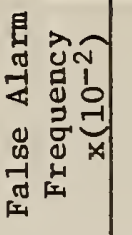 & 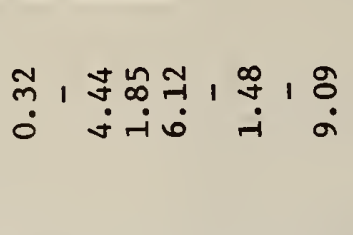 & 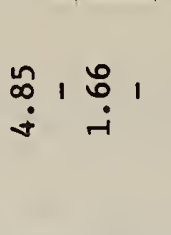 & 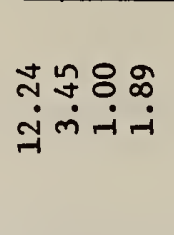 & 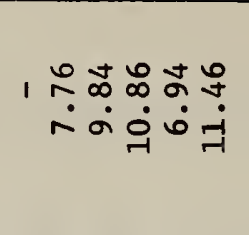 & $\stackrel{m}{\stackrel{9}{0}}$ & 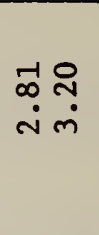 & 윰 \\
\hline 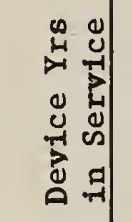 & o욜 & 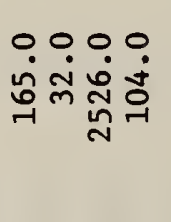 & 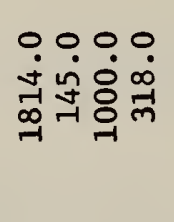 & 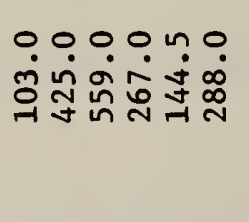 & กี & $\begin{array}{l}n 0 \\
\stackrel{\infty}{0} \frac{0}{n}\end{array}$ & 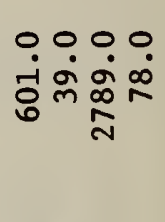 \\
\hline 永 & ODOHNOAOO & O०Mn & $\operatorname{nmmm}$ & ormmom & 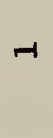 & \pm 0 & HO \\
\hline 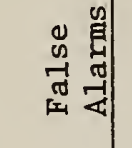 & HON & $\infty \circ \underset{\mathcal{N}}{\infty}$ & Nิ $\operatorname{No}^{\circ}$ & 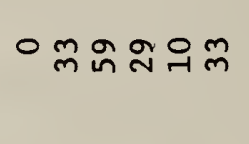 & $m$ & $\stackrel{\infty}{\sim} r$ & moन्ન \\
\hline 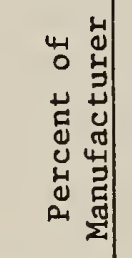 & 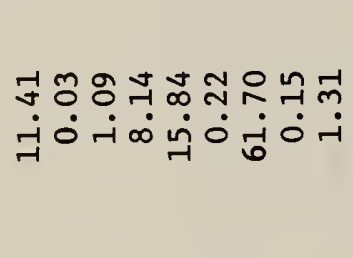 & थี & 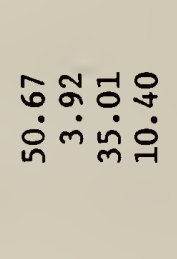 & 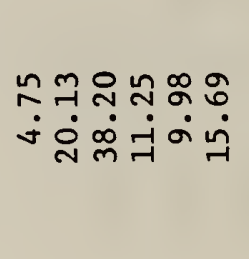 & $\stackrel{0}{8}$ & 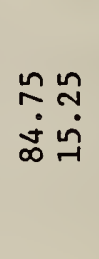 & 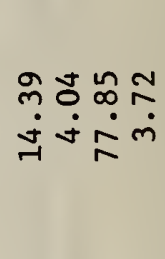 \\
\hline 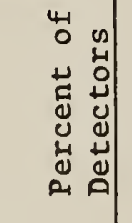 & 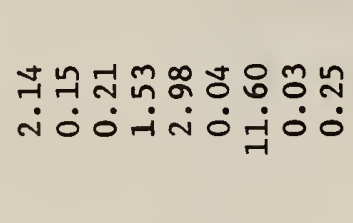 & 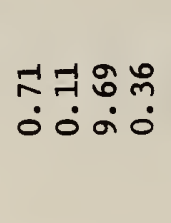 & $\begin{array}{l}9 \stackrel{\infty}{9} \hat{N} \hat{N} \\
\dot{0} \dot{0}\end{array}$ & 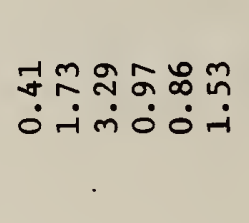 & $\begin{array}{l}\sigma \\
\dot{\sigma}\end{array}$ & 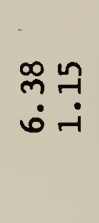 & 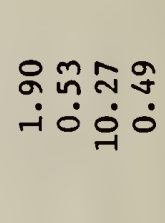 \\
\hline 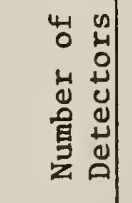 & 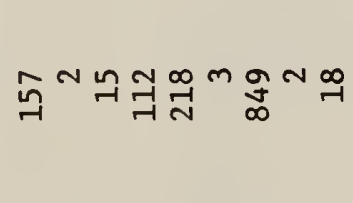 & 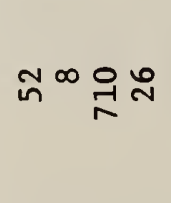 & 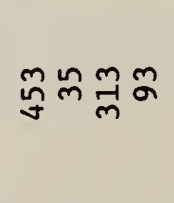 & 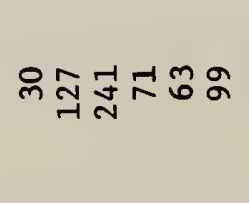 & : & $\hat{\sigma}^{ \pm}$ & ले \\
\hline $\begin{array}{ll}-1 & 4 \\
0 & 0 \\
0 & 0 \\
0 & 0 \\
& 0\end{array}$ & $0 ન N m \cup \ln 0 \sim \infty$ & OHNm & OHNM & $O-N m \circlearrowleft n$ & 0 & $0-1$ & $0-N m$ \\
\hline 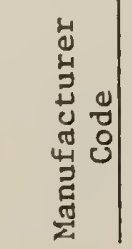 & $\varangle$ & $\infty$ & 0 & D & by & Fa & 0 \\
\hline
\end{tabular}




\begin{tabular}{|c|c|c|c|c|c|c|}
\hline 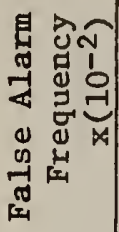 & 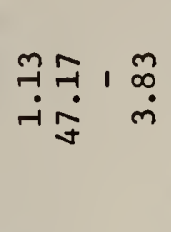 & 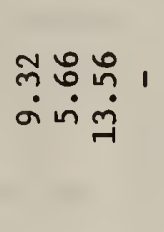 & 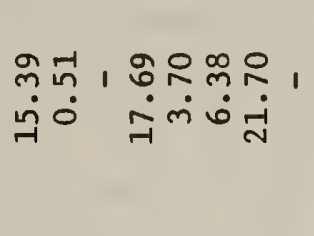 & 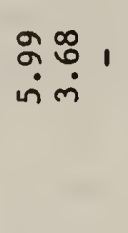 & in & $\begin{array}{l}8 \\
\dot{0} \\
\dot{8} \\
0\end{array}$ \\
\hline 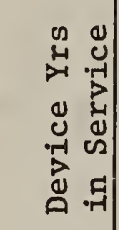 & $\begin{array}{l}0000 \\
\dot{0} \dot{0} \text { i } \\
\text { ñ } \\
m\end{array}$ & 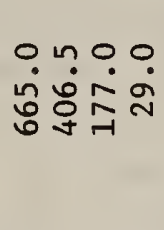 & 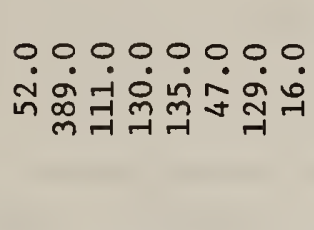 & O थ & $\frac{\dot{n}}{n}$ & 过宾 \\
\hline 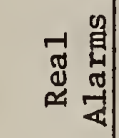 & m too & -1000 & OOONNHOO & NoO & N & om \\
\hline 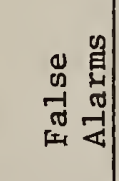 & $\checkmark$ 유의 & ฟิ సั & $\infty \sim \underset{\sim}{n} n \underset{N}{\infty}$ & $\tilde{n}^{m o}$ & స్ & +0 \\
\hline 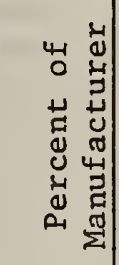 & 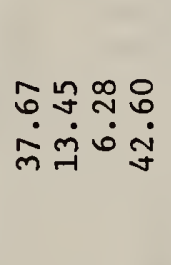 & 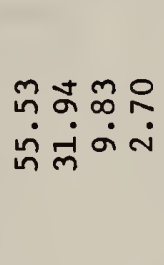 & 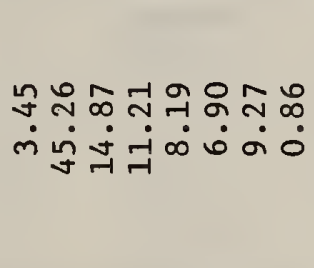 & 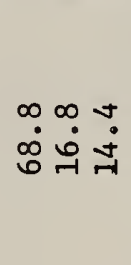 & $\stackrel{\circ}{\circ}$ & में \\
\hline 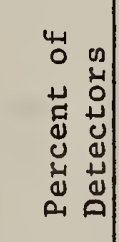 & 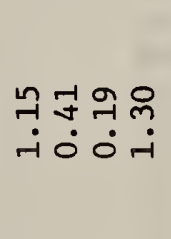 & 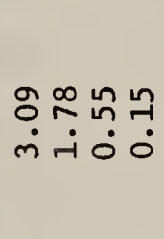 & 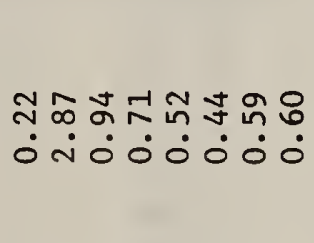 & 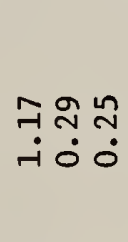 & $\begin{array}{l}\tilde{O} \\
\dot{\sim}\end{array}$ & $\begin{array}{l}m \\
0 \\
0 \\
0 \\
0\end{array}$ \\
\hline 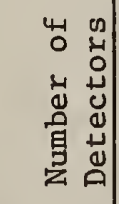 & 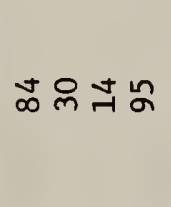 & 츅억억 & 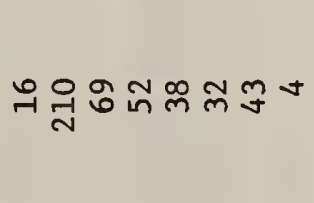 & 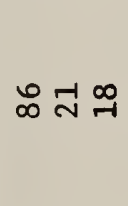 & $\stackrel{\infty}{\underset{1}{+1}}$ & N \\
\hline 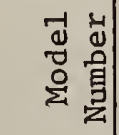 & $O H N m$ & $O H N M$ & OHNm & $0-N$ & 0 & $0-1$ \\
\hline 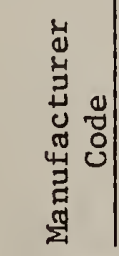 & 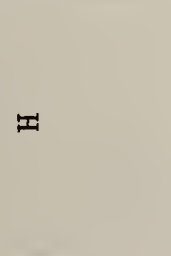 & $\mapsto$ & $\mapsto$ & $\forall$ & $\mapsto$ & $\Sigma$ \\
\hline
\end{tabular}


Table A3. Summary of results by type of facility

\begin{tabular}{|l|c|c|c|c|c|c|}
\hline $\begin{array}{c}\text { Type of } \\
\text { Facility }\end{array}$ & $\begin{array}{c}\text { Number } \\
\text { of Forms }\end{array}$ & $\begin{array}{c}\text { Percent } \\
\text { of Forms }\end{array}$ & $\begin{array}{c}\text { Number of } \\
\text { Detectors }\end{array}$ & $\begin{array}{c}\text { Percent of } \\
\text { Detectors }\end{array}$ & $\begin{array}{c}\text { Real } \\
\text { Alarms }\end{array}$ & $\begin{array}{c}\text { False } \\
\text { Alarms }\end{array}$ \\
\hline $\begin{array}{c}\text { Nursing } \\
\text { Home }\end{array}$ & 892 & 88.40 & 5290 & 85.89 & 63 & 903 \\
Hospital & 117 & 11.60 & 1033 & 14.11 & 15 & 185 \\
\hline Totals & 1009 & 100.00 & 7323 & 100.00 & 78 & 1088 \\
\hline
\end{tabular}

False alarm to real alarm ratio for nursing homes: 14.3:1

False alarm to real alarm ratio for hospitals: 12.4:1

False alarm to real alarm ratio for all health care facilities: 14.0:1
Pall

Table A4. Summary of results by time in service

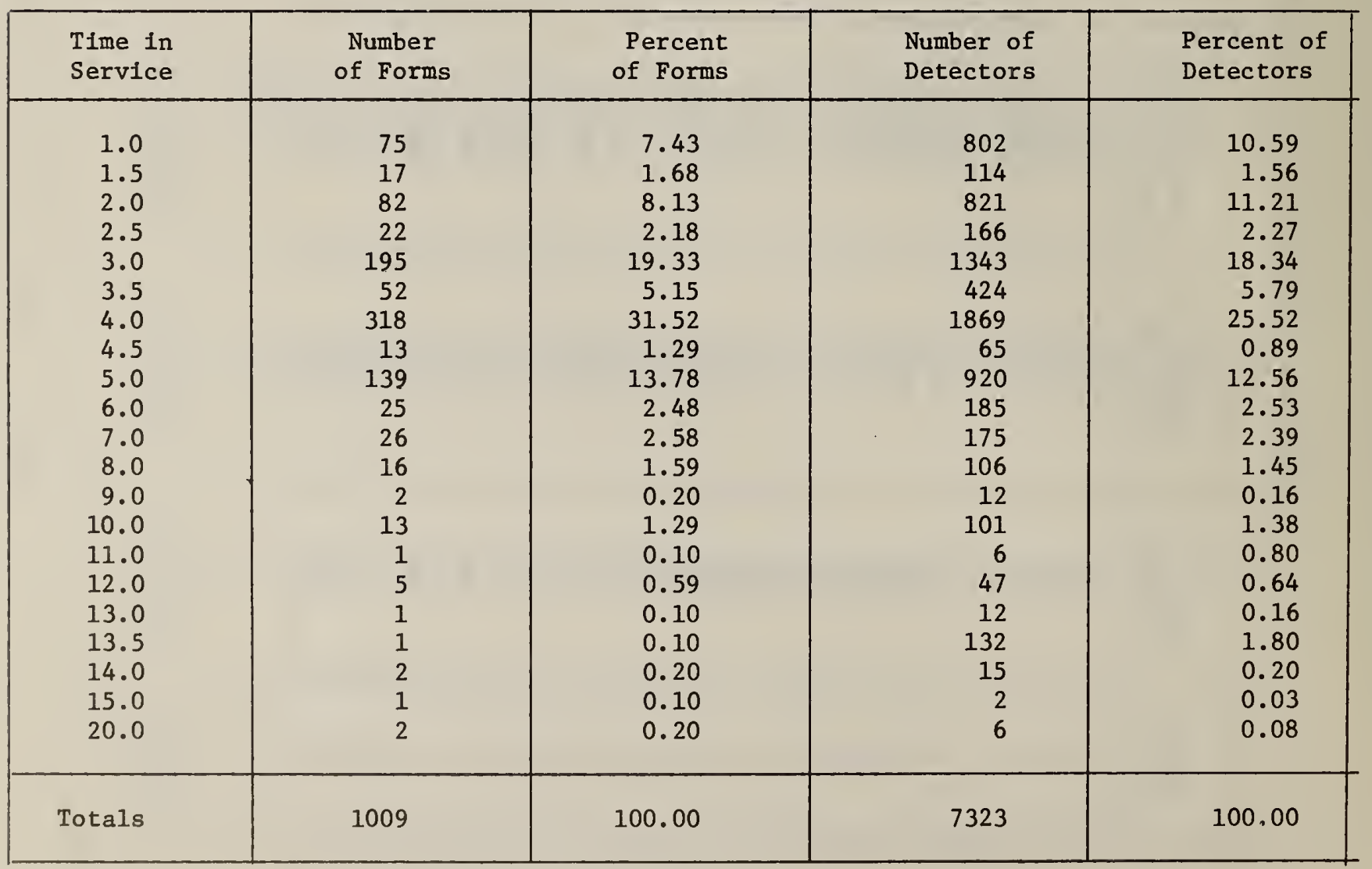




\begin{tabular}{|c|c|c|c|c|c|c|c|c|c|}
\hline 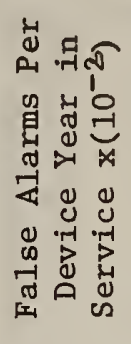 & $\begin{array}{l}\text { ठे } \\
\text { iे }\end{array}$ & $\stackrel{m}{\ddot{j}}$ & $\begin{array}{l}8 \\
\text { ஸे }\end{array}$ & 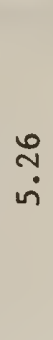 & $\begin{array}{l}\stackrel{n}{N} \\
\stackrel{m}{m}\end{array}$ & $\begin{array}{l}\stackrel{N}{\infty} \\
\dot{m}\end{array}$ & $\begin{array}{l}8 \\
0 \\
\dot{0}\end{array}$ & $\stackrel{\vec{H}}{\stackrel{H}{r}}$ & in \\
\hline 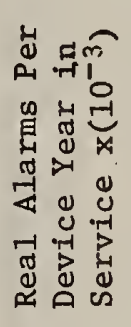 & ò & @े & 1 & $\begin{array}{l}\hat{b} \\
\dot{\sim} \\
\text { กิ }\end{array}$ & $\begin{array}{l}\text { 우 } \\
\text { i் }\end{array}$ & 1 & & 1 & $\hat{i}$ \\
\hline 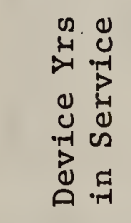 & $\underset{\substack{+ \\
\text { i }}}{0}$ & $\begin{array}{l}0 \\
0 \\
0 \\
0 \\
0 \\
0-1\end{array}$ & $\stackrel{0}{\dot{+}}$ & $\begin{array}{l}\circ \\
\dot{m}\end{array}$ & $\begin{array}{l}0 \\
\text { ले }\end{array}$ & $\begin{array}{l}0 \\
\dot{j} \\
\vec{m}\end{array}$ & $\stackrel{0}{\dot{\theta}}$ & $\begin{array}{l}0 \\
\dot{9} \\
\dot{\sigma}\end{array}$ & 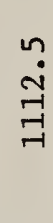 \\
\hline 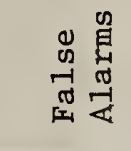 & $\stackrel{\infty}{\sim}$ & $\hat{n}$ & 욱 & $N$ & 욱 & $\underset{\sim}{\sim}$ & $\checkmark$ & 욱 & mे \\
\hline 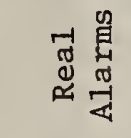 & $\underset{r}{ \pm}$ & in & 0 & $N$ & $N$ & 0 & 0 & 0 & $m$ \\
\hline 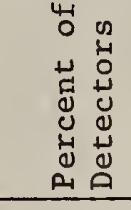 & $\begin{array}{l}\text { શે } \\
\text { ते }\end{array}$ & $\stackrel{\text { mे }}{\dot{r}}$ & $\stackrel{n}{r-1}$ & $\begin{array}{l}\text { Ir } \\
\dot{0}\end{array}$ & $\begin{array}{l}\text { 감 } \\
\stackrel{0}{0}\end{array}$ & $\underset{\text { ָi }}{\stackrel{+}{+}}$ & 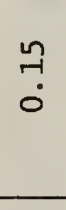 & $\stackrel{m}{\tilde{0}}$ & $\underset{+}{7}$ \\
\hline 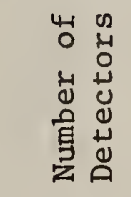 & $\begin{array}{l}-1 \\
0 \\
\\
-1\end{array}$ & $\underset{\sim}{N}$ & $\vec{F}$ & $a$ & $\infty$ & ब̆ & ન & gे & $\stackrel{n}{\tilde{m}}$ \\
\hline 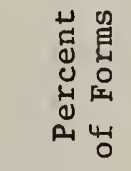 & \begin{tabular}{l}
\multirow{U}{*}{} \\
$\dot{0}$
\end{tabular} & 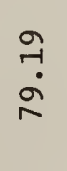 & 유 & $\stackrel{\circ}{\stackrel{P}{0}}$ & $\stackrel{a}{i}$ & 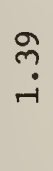 & $\stackrel{9}{\stackrel{0}{0}}$ & $\stackrel{\infty}{\sigma}$ & $\stackrel{m}{m}$ \\
\hline 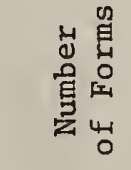 & $\hat{0}$ & হ & in & $\checkmark$ & $\infty$ & $\vec{\tau}$ & $\infty$ & 오 & $\underset{\infty}{+}$ \\
\hline 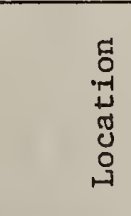 & 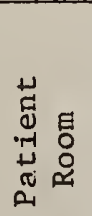 & \begin{tabular}{l} 
H \\
0 \\
0 \\
$0-1$ \\
\multicolumn{4}{|c}{} \\
0 \\
0
\end{tabular} & 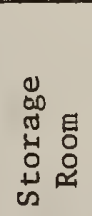 & 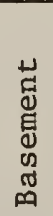 & 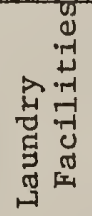 & 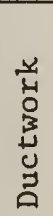 & 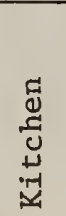 & 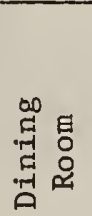 & 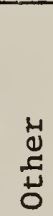 \\
\hline
\end{tabular}


Table A6. Summary of results by number of detectors

\begin{tabular}{|c|c|c|c|c|c|}
\hline $\begin{array}{l}\text { Number of } \\
\text { Detectors }\end{array}$ & $\begin{array}{c}\text { Number } \\
\text { of Forms }\end{array}$ & $\begin{array}{l}\text { Percent } \\
\text { of Forms }\end{array}$ & $\begin{array}{l}\text { Number of } \\
\text { Detectors }\end{array}$ & $\begin{array}{c}\text { Number } \\
\text { of Forms } \\
\end{array}$ & $\begin{array}{l}\text { Percent } \\
\text { of Forms }\end{array}$ \\
\hline 1 & 94 & 9.32 & 23 & 3 & 0.30 \\
\hline 2 & 191 & 18.93 & 25 & 6 & 0.59 \\
\hline 3 & 52 & 5.15 & 26 & 3 & 0.30 \\
\hline 4 & 163 & 16.15 & 28 & 2 & 0.20 \\
\hline 5 & 25 & 2.48 & 29 & 1 & 0.10 \\
\hline 6 & 115 & 11.40 & 31 & 3 & 0.30 \\
\hline 7 & 24 & 2.38 & 34 & 2 & 0.20 \\
\hline 8 & 103 & 10.21 & 35 & 1 & 0.10 \\
\hline 9 & 17 & 1.68 & 36 & 2 & 0.20 \\
\hline 10 & 64 & 6.34 & 37 & 3 & 0.30 \\
\hline 11 & 11 & 1.09 & 38 & 2 & 0.20 \\
\hline 12 & 22 & 3.17 & 40 & 4 & 0.40 \\
\hline 13 & 13 & 1.29 & 46 & 1 & 0.10 \\
\hline 14 & 16 & 1.59 & 49 & 1 & 0.10 \\
\hline 15 & 5 & 0.50 & 53 & 1 & 0.10 \\
\hline 16 & 14 & 1.39 & 58 & 1 & 0.10 \\
\hline 17 & 1 & 0.10 & 62 & 1 & 0.10 \\
\hline 18 & 9 & 0.89 & 67 & 1 & 0.10 \\
\hline 19 & 1 & 0.10 & 100 & 1 & 0.10 \\
\hline 20 & 10 & 0.99 & 108 & 1 & 0.10 \\
\hline 21 & 4 & 0.40 & 132 & 1 & 0.10 \\
\hline \multirow[t]{2}{*}{22} & \multirow[t]{2}{*}{4} & \multirow[t]{2}{*}{0.40} & & & \\
\hline & & & Totals & 1009 & 100.00 \\
\hline
\end{tabular}

Table A7. Summary of results by false and real alarms

\begin{tabular}{|c|c|c|c|c|c|}
\hline $\begin{array}{c}\text { Number of } \\
\text { False Alarms }\end{array}$ & $\begin{array}{l}\text { Number } \\
\text { of Forms } \\
\end{array}$ & $\begin{array}{l}\text { Percent } \\
\text { of Forms }\end{array}$ & $\begin{array}{c}\text { Number } \\
\text { Real Alarms }\end{array}$ & $\begin{array}{c}\text { Number } \\
\text { of Forms } \\
\end{array}$ & $\begin{array}{l}\text { Percent } \\
\text { of Forms }\end{array}$ \\
\hline $\begin{array}{r}0 \\
1 \\
2 \\
3 \\
4 \\
5 \\
6 \\
7 \\
8 \\
9 \\
10 \\
11 \\
12 \\
15 \\
16 \\
18 \\
20 \\
23 \\
24 \\
28 \\
29 \\
50 \\
60 \\
87\end{array}$ & $\begin{array}{r}804 \\
55 \\
47 \\
25 \\
15 \\
14 \\
7 \\
4 \\
8 \\
5 \\
6 \\
1 \\
3 \\
3 \\
1 \\
1 \\
1 \\
1 \\
3 \\
1 \\
1 \\
1 \\
1 \\
1\end{array}$ & $\begin{array}{r}79.68 \\
5.45 \\
4.66 \\
2.48 \\
1.49 \\
1.39 \\
0.69 \\
0.40 \\
0.79 \\
0.50 \\
0.59 \\
0.10 \\
0.30 \\
0.30 \\
0.10 \\
0.10 \\
0.10 \\
0.10 \\
0.30 \\
0.10 \\
0.10 \\
0.10 \\
0.10 \\
0.10\end{array}$ & $\begin{array}{l}0 \\
1 \\
2 \\
3 \\
5\end{array}$ & $\begin{array}{r}949 \\
47 \\
10 \\
2 \\
1\end{array}$ & $\begin{array}{r}94.05 \\
4.66 \\
0.99 \\
0.20 \\
0.10\end{array}$ \\
\hline
\end{tabular}




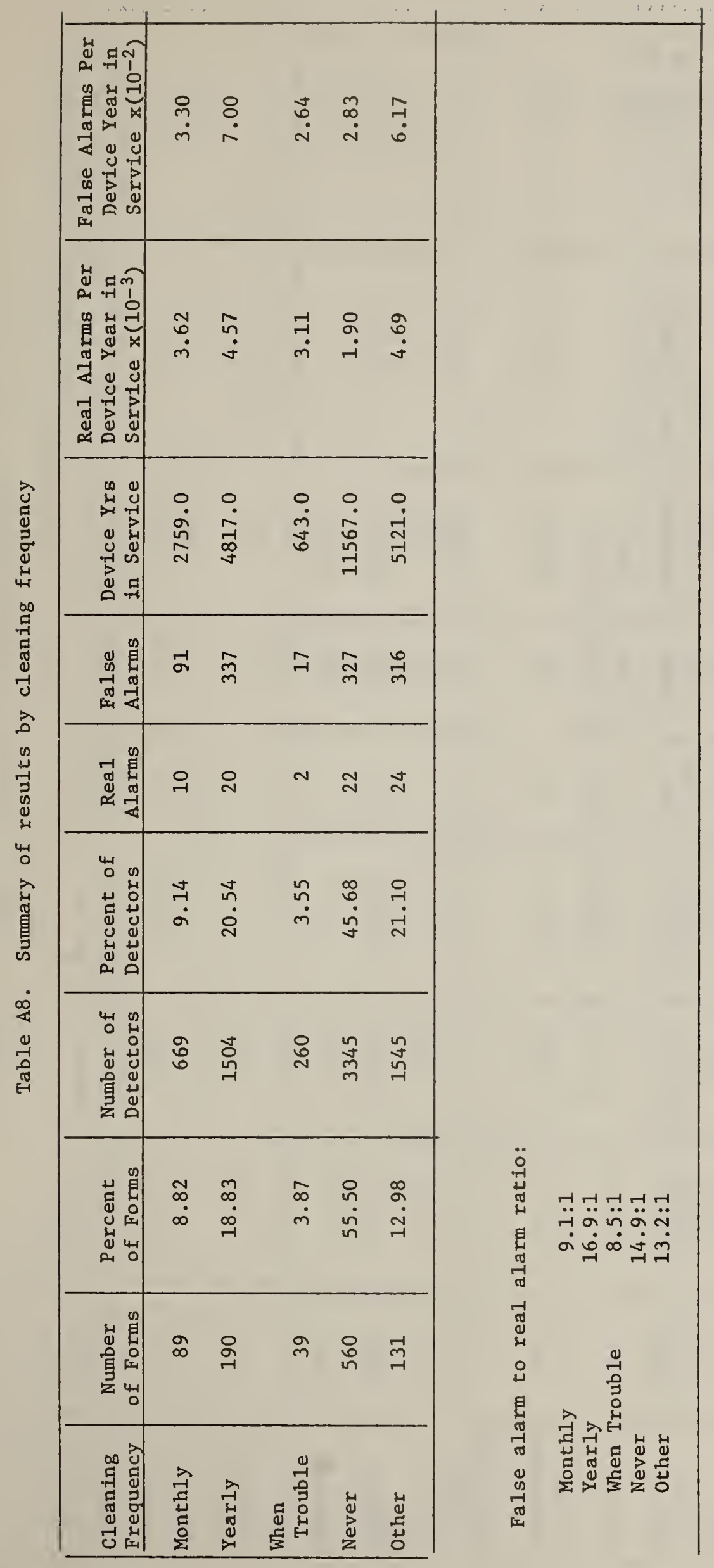




\begin{tabular}{|c|c|c|c|c|c|c|c|c|c|}
\hline 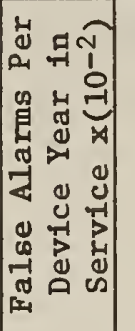 & $\stackrel{0}{0}$ & 옴 & $\stackrel{\infty}{\stackrel{0}{0}}$ & $\begin{array}{l}\text { ณ } \\
\text { ம் }\end{array}$ & 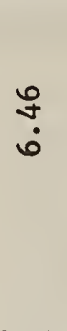 & $\stackrel{\infty}{\stackrel{\infty}{\sim}}$ & 1 & $\begin{array}{l}m \\
\infty \\
\dot{N}\end{array}$ & $\stackrel{m}{r}$ \\
\hline 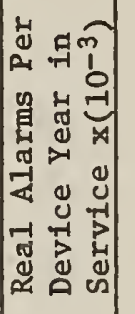 & $\begin{array}{l}\text { N } \\
\text { - }\end{array}$ & ஸे & 1 & $\begin{array}{l}0 \\
\infty \\
\dot{i}\end{array}$ & $\underset{\vec{j}}{\vec{j}}$ & f. & $\stackrel{m}{m}$ & $\stackrel{\infty}{\tilde{r}}$ & 1 \\
\hline 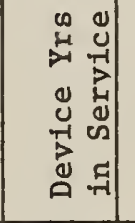 & $\begin{array}{l}0 \\
\stackrel{0}{ } \\
\infty \\
-1 \\
\sim\end{array}$ & $\begin{array}{l}0 \\
\dot{0} \\
\stackrel{+}{+}\end{array}$ & $\begin{array}{l}0 \\
\dot{\infty} \\
\underset{\sim}{\sim}\end{array}$ & $\begin{array}{l}0 \\
\dot{n} \\
\stackrel{N}{N}\end{array}$ & $\begin{array}{l}0 \\
\dot{0} \\
\infty \\
\infty \\
\text { N }\end{array}$ & $\underset{\stackrel{0}{N}}{\stackrel{i}{N}}$ & 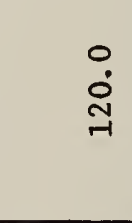 & $\begin{array}{l}0 \\
\hat{0} \\
\stackrel{0}{n} \\
\end{array}$ & $\begin{array}{l}0 \\
\dot{-1} \\
\stackrel{-}{J} \\
\vec{H}\end{array}$ \\
\hline 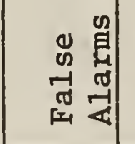 & 营 & ભำ & -1 & $\underset{-1}{J}$ & $\underset{\infty}{\infty}$ & 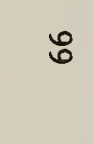 & 0 & $\stackrel{\widetilde{N}}{\sim}$ & ᄋ̊ \\
\hline 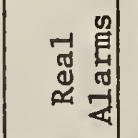 & + & $a$ & 0 & $\infty$ & テี & $\stackrel{m}{-1}$ & $r$ & N & $a$ \\
\hline 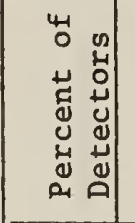 & $\begin{array}{l}m \\
\stackrel{m}{+} \\
\infty\end{array}$ & 요 & $\stackrel{\infty}{m}$ & $\begin{array}{l}+1 \\
0 \\
0 \\
0\end{array}$ & $\stackrel{m}{\dddot{m}}$ & $\underset{⿱}{\stackrel{9}{0}}$ & $\begin{array}{l}\dot{J} \\
\dot{0}\end{array}$ & $\begin{array}{l}\infty \\
0 \\
\dot{b} \\
\stackrel{0}{y}\end{array}$ & $\begin{array}{l}\exists \\
\dot{y}\end{array}$ \\
\hline 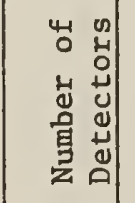 & • 乞n & $\begin{array}{l}\infty \\
\infty \\
m\end{array}$ & $\stackrel{\infty}{\sim}$ & $\stackrel{m}{r}$ & $\frac{0}{a}$ & 옴 & స̃ & $\stackrel{n}{\tilde{m}}$ & I \\
\hline 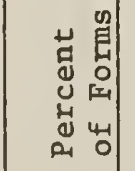 & $\stackrel{-1}{\tilde{7}}$ & $\stackrel{2}{9}$ & 웅 & $\begin{array}{l}m \\
\infty \\
\stackrel{\infty}{0}\end{array}$ & $\begin{array}{l}\text { Jै } \\
\dot{0}\end{array}$ & $\stackrel{m}{m}$ & 유 & $\begin{array}{l}\text { 우 } \\
\text { in } \\
\text { ผn }\end{array}$ & ษீ \\
\hline 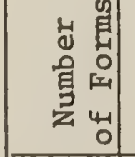 & ঞ & $\mathscr{8}$ & $\checkmark$ & 9 & $\hat{\sigma}$ & ఎ & in & 윰 & $\stackrel{f}{q}$ \\
\hline 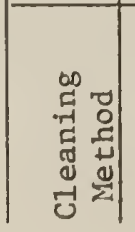 & $\begin{array}{l}\text { 目 } \\
\text { 己 } \\
\text { ग } \\
>\end{array}$ & $\begin{array}{l}\text { U } \\
\text { On } \\
\vec{B}\end{array}$ & 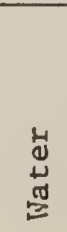 & $\frac{7}{4}$ & $\begin{array}{l}-1 \\
0 \\
\frac{1}{0} \\
0 \\
-1 \\
-4\end{array}$ & 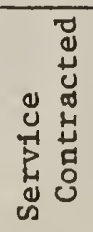 & 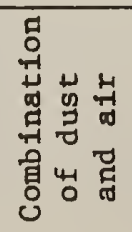 & 离 & 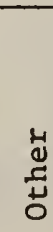 \\
\hline
\end{tabular}




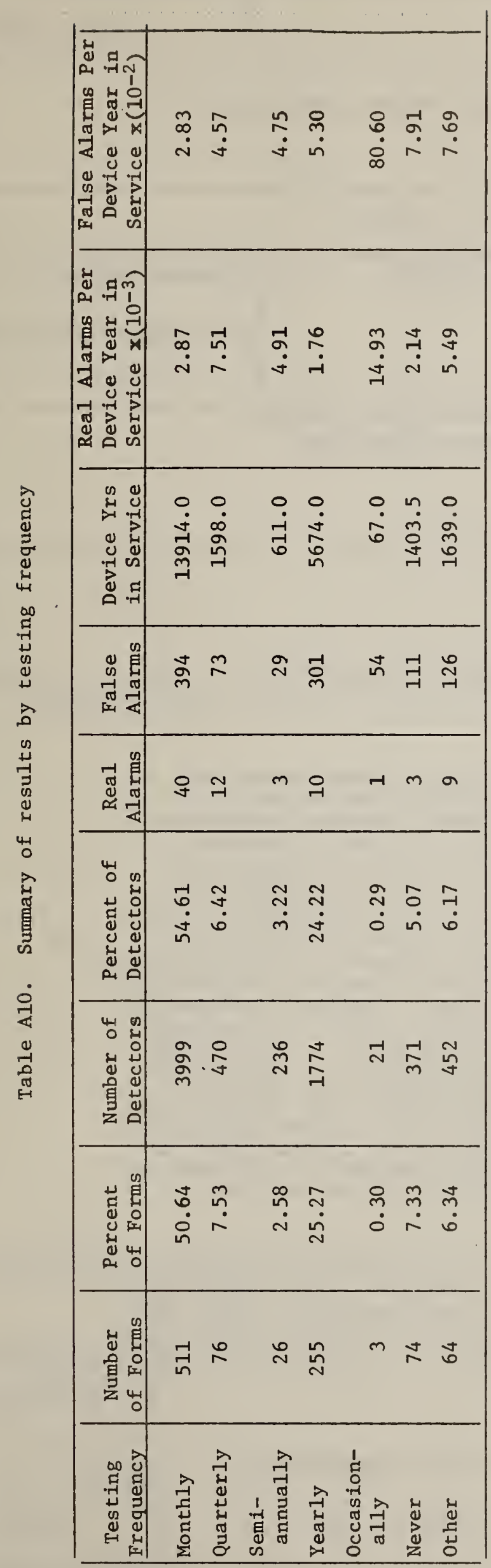

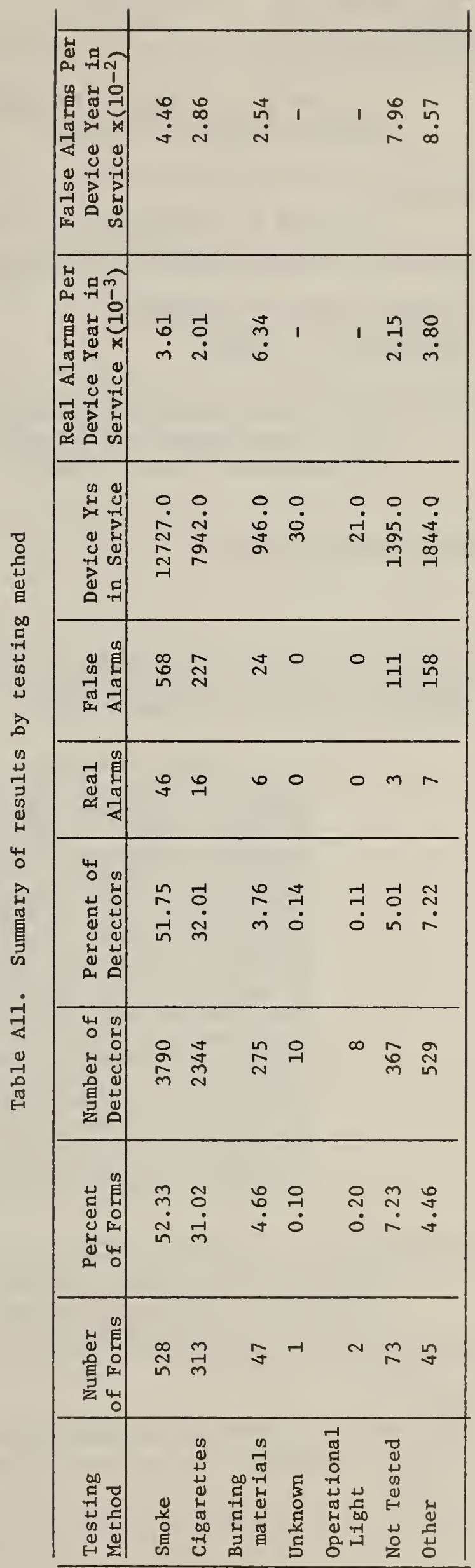


U.S. DEPT. OF COMM.

BIBLIOGRAPHIC DATA

SHEET (See instruction s)
1. PUBLICATION OR

REPORT NO.

NBSIR $80-2130$
2. Performing Organ. Report Noy 3. Publication Date

October 1980

4. TITLE AND SUBTITLE

\section{A SURVEY OF FIELD EXPERIENCE WITH SMOKE DETECTORS IN HEALTH CARE FACILITIES}

5. $A \cup T H O R(S)$

Richard W. Bukowski and Sharon M. Istvan

6. PERFORMING ORGANIZATION (If joint or other than NBS, see instructions)

7. Contract/Grant No.

NATIONAL BUREAU OF STANDARDS

DEPARTMENT OF COMMERCE

WASHINGTON, D.C. 20234

8. Type of Report \& Period Covered

Final

9. SPONSORING ORGANIZATION NAME AND COMPLETE ADCRESS (Streel, City, StUTe, ZIF)

U.S. Department of Health and Human Services

Washington, D.C. 20201

10. SUPPLEMENTARY NOTES

Document describes a computer program; SF-185, FIPS Software Summary, is attached.

11. ABSTRACT (A 200-word or less factual summary of most significant information. If document includes a significant bibliography or literature survey. mention it here)

A survey of health care facilities in eight states was conducted to gather data on experience with smoke detection systems. Requested information included detector manufacturer and model number, number of detectors and time in service, detector locations, numbers of false and real alarms and the methods and frequency of cleaning and testing the detectors. The results of the survey indicate that about 70 percent of the detectors were ionization type, and 30 percent were of the photoelectric type. Fourteen percent of the total number of detectors were single-station, battery-operated, residential-type detectors, most of which were installed in health care facilities in only one of the eight states surveyed. Almost 80 percent of the detectors were installed in corridors and the average age of the detector installation was about five years. The detection systems were found to experience approximately 14 false alarms for each real fire detected with the highest false alarm rate occurring in detectors installed in laundry areas, storage areas, and kitchens. While over 88 percent of the systems were tested at least annually ( 55 percent tested monthly), almost half ( 45.7 percent) were never cleaned. Almost 11 percent of the installed systems were maintained under an outside service contract.

12. KEY WORDS (Six to twelve entries; alphabetical order: capitalize only proper names; and separate key words by semicalons)

Detector location; false alarms; health care facilities;

hospitals; ionization detectors; maintenance; NFPA 101;

nursing homes; photoelectric detectors; smoke detectors; surveys.

13. AVAILABILITY

[X̧ Unlimited

For Official Distribution. Do Not Release to NTIS

Order From Superintendent of Documents, U.S. Government Printing Office, Washington, D.C. 20402.
14. NO OF

PRINTED PAGES

\section{6}

15. Price

[X్der From National Technical Information Service (NTIS), Springfield, VA. 2216I

$\$ 6.00$ 

$\frac{d}{y}$ 